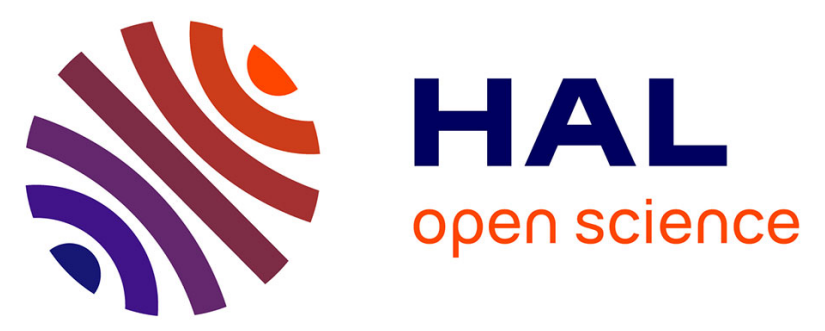

\title{
Direct fusion of subunits of heterodimeric nitric oxide sensitive guanylyl cyclase leads to functional enzymes with preserved biochemical properties: evidence for isoform specific activation by ciguates
}

\author{
Nadine Haase, Tobias Haase, Jan Robert Kraehling, Soenke Behrends
}

\section{To cite this version:}

Nadine Haase, Tobias Haase, Jan Robert Kraehling, Soenke Behrends. Direct fusion of subunits of heterodimeric nitric oxide sensitive guanylyl cyclase leads to functional enzymes with preserved biochemical properties: evidence for isoform specific activation by ciguates. Biochemical Pharmacology, 2010, 80 (11), pp.1676. 10.1016/j.bcp.2010.08.007 . hal-00632287

\section{HAL Id: hal-00632287 \\ https://hal.science/hal-00632287}

Submitted on 14 Oct 2011

HAL is a multi-disciplinary open access archive for the deposit and dissemination of scientific research documents, whether they are published or not. The documents may come from teaching and research institutions in France or abroad, or from public or private research centers.
L'archive ouverte pluridisciplinaire HAL, est destinée au dépôt et à la diffusion de documents scientifiques de niveau recherche, publiés ou non, émanant des établissements d'enseignement et de recherche français ou étrangers, des laboratoires publics ou privés. 


\section{Accepted Manuscript}

Title: Direct fusion of subunits of heterodimeric nitric oxide sensitive guanylyl cyclase leads to functional enzymes with preserved biochemical properties: evidence for isoform specific activation by ciguates

Authors: Nadine Haase, Tobias Haase, Jan Robert Kraehling,

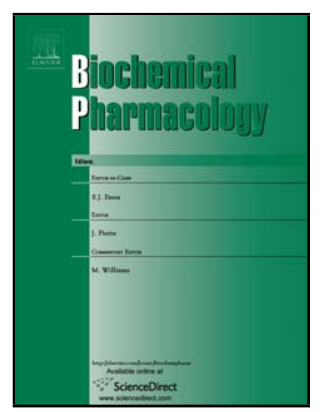

Soenke Behrends

PII:

S0006-2952(10)00616-7

DOI:

doi:10.1016/j.bcp.2010.08.007

Reference:

BCP 10686

To appear in: $\quad B C P$

Received date: $\quad 21-5-2010$

Revised date: $\quad 13-8-2010$

Accepted date: $\quad 13-8-2010$

Please cite this article as: Haase N, Haase T, Kraehling JR, Behrends S, Direct fusion of subunits of heterodimeric nitric oxide sensitive guanylyl cyclase leads to functional enzymes with preserved biochemical properties: evidence for isoform specific activation by ciguates, Biochemical Pharmacology (2010), doi:10.1016/j.bcp.2010.08.007

This is a PDF file of an unedited manuscript that has been accepted for publication. As a service to our customers we are providing this early version of the manuscript. The manuscript will undergo copyediting, typesetting, and review of the resulting proof before it is published in its final form. Please note that during the production process errors may be discovered which could affect the content, and all legal disclaimers that apply to the journal pertain. 
Direct fusion of subunits of heterodimeric nitric oxide sensitive guanylyl cyclase leads to functional enzymes with preserved biochemical properties: evidence for isoform specific activation by ciguates

Nadine Haase ${ }^{1}$, Tobias Haase ${ }^{2}$, Jan Robert Kraehling ${ }^{3}$, and Soenke Behrends ${ }^{4}$

University of Braunschweig - Institute of Technology, Department of Pharmacology, Toxicology and Clinical Pharmacy

Address correspondence to:

Dr. Soenke Behrends, University of Braunschweig - Institute of Technology, Department of Pharmacology, Toxicology and Clinical Pharmacy, Mendelssohnstrasse 1, 38106 Braunschweig, Germany, Phone: +49 531391 5604, Fax: +49 531391 8182, e-mail: s.behrends@tubraunschweig.de 


\section{Abstract}

Nitric oxide sensitive guanylyl cyclase (NOsGC) is a heterodimeric enzyme consisting of an $\alpha$ and a $\beta$ subunit. Two heterodimeric enzymes are known to be important for NO-signalling in humans: $\alpha_{1} / \beta_{1}$ and $\alpha_{2} / \beta_{1}$. No difference had so far been detected with respect to their pharmacological properties, but as we show in the present paper the new drugs cinaciguat and ataciguat activate the $\alpha_{1} / \beta_{1}$ form more effectively. Recent evidence suggests that homodimeric complexes of $\alpha$ and $\beta$ subunits exist in vivo and that these non-heterodimerizing subunits have a separate function from cGMP signaling. To isolate the effect of the $\alpha_{1} / \beta_{1}$ or $\alpha_{2} / \beta_{1}$ heterodimeric enzyme in overexpression experiments from potential effects of non-heterodimerizing $\alpha_{1}, \beta_{1}$ or $\alpha_{2}$ subunits, we cloned constructs that guarantee a 1:1 stochiometry between $\alpha$ and $\beta$ subunits and rule out the presence of homodimers. The carboxy-terminus of the $\beta_{1}$ subunit was directly fused to the amino-terminus of either the $\alpha_{1}$ or $\alpha_{2}$ subunit. The two different "conjoined" NOsGCs faithfully reproduced the biochemical and pharmacological properties of the $\alpha_{1} / \beta_{1}$ and $\alpha_{2} / \beta_{1}$ heterodimeric enzymes including the differential activation by ciguat-activators. Conjoined NOsGCs can be used for isoform specific overexpression in transgenic animals and therapeutic overexpression may be an application in the future. In both cases possible side effects of homodimeric $\alpha$ or $\beta$ subunits are avoided. Crystallization with the goal of structure determination may also be easier for conjoined NOsGCs because enzyme preparations are more homogenous and are free of "contaminating" homodimers. 


\section{Introduction}

Nitric oxide sensitive guanylyl cyclase (NOsGC) is the major physiological receptor for nitric oxide (NO) throughout the cardiovascular and central nervous system (for reviews see [1] and [2]). Two heterodimeric enzymes are known to be important for NO-signalling in humans: $\alpha_{1} / \beta_{1}$ and $\alpha_{2} / \beta_{1}$. Both catalyze the production of the second messenger molecule cGMP from GTP. Only the $\alpha_{2} / \beta_{1}$ isoform can interact with the PDZ containing protein PSD-95 via its carboxy-terminal sequence and seems to adhere to specialized membrane compartments in some tissues [3]. No other difference has so far been detected in the biochemical and pharmacological properties of both purified enzyme isoforms [4].

It has been shown that co-expression of the $\alpha_{1}$ and $\beta_{1}$ subunit in overexpression systems leads to the formation of $\alpha_{1}$ homodimers and $\beta_{1}$ homodimers in addition to heterodimers [5]. Since the homodimers are inactive with respect to cGMP formation Zabel et al. suggested the possibility of a physiological equilibrium between homo- and heterodimeric NOsGC complexes and a possible regulation of NOsGC activity by the extent of homodimerization versus heterodimerization. In support of such a concept we have recently shown that NOsGC activity decreases during cerebral postnatal development because of a reduction in heterodimerization and have demonstrated the occurrence of non-heterodimerizing $\alpha_{1}$ or $\beta_{1}$ subunits in vivo [6]. Intriguingly there is recent evidence to suggest that both the isolated $\alpha_{1}$ subunit and the isolated $\beta_{1}$ subunit have a separate function from cGMP signalling: The $\alpha_{1}$ subunit seems to act as an important mediator of the procarcinogenic effect of androgens [7-8]. The $\beta_{1}$ subunit has been suggested to regulate chromatin condensation and cell cycle progression [9].

To isolate the effect of the $\alpha_{1} / \beta_{1}$ and $\alpha_{2} / \beta_{1}$ heterodimeric enzyme in overexpression experiments from potential effects of non-heterodimerizing $\alpha_{1}, \beta_{1}$ or $\alpha_{2}$ subunits, we cloned 
constructs that guarantee a 1:1 stochiometry between $\alpha$ and $\beta$ subunits and rule out the presence of homodimers. Here we provide the pharmacological and biochemical characterization of these "conjoined" NOsGCs. Conjoined NOsGCs will allow facilitated overexpression in transgenic animals and will exclude overexpression of non-heterodimerizing subunits that have effects independent of cGMP signalling. Crystallization with the goal of structure determination should be easier for conjoined NOsGC because enzyme preparations are more homogenous and are free of "contaminating" $\beta_{1}$ homodimers or $\alpha$ homodimers. In addition to providing a novel tool for research, we provide the first evidence of a pharmacological difference between $\alpha_{1} / \beta_{1}$ and $\alpha_{2} / \beta_{1}$ heterodimeric enzymes: The ciguat-activators which are currently being developed clinically for the treatment of heart failure and other cardiovascular disease states are more effective activators of the $\alpha_{1} / \beta_{1}$ isoform. 


\section{Materials and Methods}

\subsection{Materials}

3-(5'-Hydroxymethyl-2'-furyl)-1-benzylindazole $\quad$ (YC-1), 1H-[1,2,4]oxadiazolo[4,3a]quinoxalin-1-one (ODQ) and 2,2-diethyl-1-nitroso-oxyhydrazine (DEA/NO) and all other chemicals, in the highest grade of purity, were obtained from Sigma Aldrich (Munich, Germany). Cinaciguat (BAY 58-2667) was a generous gift from Johannes-Peter Stasch (Bayer Schering Pharma, Wuppertal, Germany). Ataciguat (HMR 1766) was a generous gift from Sanofi-Aventis (Frankfurt, Germany). Products for Sf9 cell culture were from Invitrogen (Karlsruhe, Germany). Restriction enzymes and polymerases were obtained from NEB (Frankfurt, Germany).

\subsection{Cloning of fluorescent tagged NOsGC subunits}

The $\beta_{1}$ subunit cDNA was amplified by RT-PCR from rat heart using cDNA Polymerase Mix and the primer pair P141 (5'-CCG ACA CCA TGT ACG GTT TTG TGA-3') and P180 (5'GGG CCC AGT TTT CAT CCT GGT TTG TTT CCT-3'). The resulting PCR product was subcloned into pcDNA3.1/V5/His-TOPO. From this construct the $\beta_{1}$ subunit cDNA was cloned HindIII/ApaI into pEYFP-N1. $\beta_{1}$ YFP construct was cloned SpeI/XbaI from $\mathrm{pEYFP-N1}$ into pFASTBAC (Invitrogen; Karlsruhe, Germany).

The NOsGC $\alpha_{1}$ subunit was amplified from rat cDNA using the primer pair: P178 (5' -ACA CCG GCT AAT AAG GAG GAA ACC AC-3') and P179 (5'-ATC TAC CCC TGA GGC CTT GCC TAA GAA-3'). The resulting PCR product was subcloned into pcDNA3.1/V5/His-TOPO (Invitrogen; Karlsruhe, Germany). From this construct the $\alpha_{1}$ cDNA was cloned HindIII/XhoI 
into HindIII/SalI pEYFP-N1 (Clontech; Saint-Germain-en-Laye, France). The carboxy-terminally YFP tagged $\alpha_{1}$ subunit was cloned NheI/XbaI into SpeI/XbaI pFASTBAC.

The $\alpha_{2}$ NOsGC subunit was cloned BamHI/SspI from pFASTBAC [10] into BglII/BamHI (Klenow fill in) in pEGFP-N1 (Clontech; Saint-Germain-en-Laye, France). From this construct the $\alpha_{2}$ subunit was cloned Eco47III/NotI into pECFP-N1(Clontech; Saint-Germain-en-Laye, France) to get the $\alpha_{2}$ CFP construct. The carboxy-terminally CFP tagged $\alpha_{2}$ subunits was cloned Eco47III/NotI into StuI/NotI pFASTBAC vector. ECFP was exchanged with EYFP from pEYFPC1 (Clontech; Saint-Germain-en-Laye, France) using AgeI/KpnI restriction sites.

\subsection{Cloning of conjoined NOsGC}

For $\beta_{1} \alpha_{1}$ conjoined NOsGC: the $\alpha_{1}$ subunit in pcDNA3.1/V5/His-TOPO was amplified by PCR using the primer pair: P270 (5'-GAT CGT GTA CAA GAT GTT CTG CAG GAA GTT CAA AG-3') and P269 (5'-GAT CGT CTA GAT TAA TCT ACC CCT GAG GCC TTG CC-3') to create new restriction sites 5' (BsrGI) and 3'(XbaI) of the $\alpha_{1}$ gene. The resulting PCR product was subcloned into pCR2.1TOPO (Invitrogen; Karlsruhe, Germany). From this construct the $\alpha_{1}$ NOsGC subunit was cloned BsrGI/XbaI from pCR2.1TOPO 3' of $\beta_{1}$ YFP in pEYFP-N1 to get a $\beta_{1}$ YFP $\alpha_{1}$ construct. YFP was deleted by the restriction with BsrGI/ApaI and blunt ends were created by mung bean nuclease (NEB; Frankfurt, Germany) treatment. The $\beta_{1} \alpha_{1}$ conjoined NOsGC in pEYFP-N1 was cloned SpeI/XbaI in pFASTBAC.

For $\beta_{1} \alpha_{2}$ conjoined NOsGC: NOsGC $\alpha_{2}$ rat was cloned BstEII (Klenow fill in)/BamHI from pFASTBAC [10] into pEYFP-C1 EcoRI (Klenow fill in)/BamHI. The YFP $\alpha_{2}$ cDNA in pEYFP$\mathrm{C} 1$ was digested with BsrGI/NheI to delete YFP from the vector. In this construct $\beta_{1}$ YFP was cloned NheI/BsrGI from pEYFP-N1 resulting in the conjoined $\beta_{1} Y F P \alpha_{2}$ (in pEYFP-C1). YFP 
was deleted by the restriction with AgeI/BspEI and blunt ends were created by Pfu polymerase treatment. The $\beta_{1} \alpha_{2}$ conjoined NOsGC in pEYFP-C1 was cloned SpeI/NotI in pFASTBAC.

\subsection{Cloning of STREP tagged (S) NOsGC subunits and conjoined NOsGC}

The cDNA encoding the carboxy-terminal 228 amino acids of the rat NOsGC $\alpha_{1}$ subunit was amplified from the construct above using an antisense primer designed to fuse a carboxy-terminal STREP tag to the $\alpha_{1}$ subunit. The following primer pair was used: P289 (5'-AGC AGC TCT GGC AAG GAC AAA T-3') and P290 (5'-TCT AGA TTA TTT TTC GAA CTG CGG GTG GCT CCA ATC TAC CCC TGA GGC CTT GCC TAA G-3'). The resulting PCR product was subcloned into pCR2.1TOPO. The DNA encoding the STREP tagged carboxy-terminal part of the $\alpha_{1}$ subunit in $\mathrm{pCR} 2.1 \mathrm{TOPO}$ was cloned BstEII/XbaI into the $\beta_{1} \alpha_{1}$ conjoined NOsGC in pFASTBAC replacing the respective carboxy-terminus. Rat $\alpha_{1}$ NOsGC with a carboxy-terminal STREP tag was obtained by cloning the amino-terminal part of the rat $\alpha_{1}$ NOsGC subunit in pCR2.1TOPO SpeI / BstEII in the preceding pFASTBAC construct thereby deleting the $\beta_{1}$ subunit from the conjoined NOsGC construct.

The cDNA encoding the carboxy-terminal 133 amino acids of the rat NOsGC $\alpha_{2}$ subunit was amplified from pFASTBAC [10] using a primer designed to fuse a carboxy-terminal STREP tag to the $\alpha_{2}$ subunit. The following primer pair was used: P280 (5'-AAG ACC CAT TCA GAT GCG GAT AGG-3') and P281 (5'-TTA TTT TTC GAA CTG CGG GTG GCT CAA GAG GCT AGT TTC TCG GAG GAA CAT CG-3'). The resulting PCR product was subcloned into pCR2.1TOPO. The STREP tagged $\alpha_{1}$ subunit fragment from pCR2.1TOPO was cloned NheI/NotI into the $\beta_{1} \alpha_{2}$ conjoined NOsGC in pFASTBAC (see above).

Rat $\alpha_{2}$ NOsGC with a carboxy-terminal STREP tag was obtained by cloning the amino- 
terminal part of the rat $\alpha_{2}$ NOsGC subunit in pFASTBAC [10] NheI/BssHII in the preceding pFASTBAC construct thereby deleting the $\beta_{1}$ subunit from the conjoined NOsGC construct.

The $\beta_{1}$ subunit was also fused with a carboxy-terminal STREP tag. The fluorescent YFP from $\beta_{1}$ YFP in pFASTBAC was replaced SmaI/PvuI with the STREP tag cloned StuI/PvuI from the STREP tagged $\beta_{1} \alpha_{1}$ conjoined NOsGC in pFASTBAC.

\subsection{Generation of Recombinant Baculovirus, Sf9 Cell Culture and Expression of Recombinant Guanylyl Cyclase Subunits}

Recombinant baculovirus was generated according to the BAC-TO-BAC ${ }^{\mathrm{TM}}$ System (Invitrogen; Karlsruhe, Germany). Sf9 cells were cultured in Sf-900 II serum-free medium supplemented with $1 \%$ penicillin/streptomycin and $10 \%$ fetal calf serum. Spinner cultures were grown at $27^{\circ} \mathrm{C}$ at $140 \mathrm{rpm}$ shaking and diluted to $2 \cdot 10^{6}$ cells $/ \mathrm{ml}$ for infection.

$20 \mathrm{ml}$ or $500 \mathrm{ml}$ of cell solution were infected with the respective recombinant baculovirus stock with multiplicities of infection of 1 .

\subsection{Cytosol Preparation, Determination of Protein Concentration and Immunoprecipitation-}

$74 \mathrm{~h}$ after infection, cells were harvested and collected by centrifugation $(1500 \mathrm{~g}$ for $10 \mathrm{~min}$ at $4{ }^{\circ} \mathrm{C}$ ). All following steps were performed at $4{ }^{\circ} \mathrm{C}$ or on ice. The cell pellet from $20 \mathrm{ml}$ was resuspended in $2 \mathrm{ml}$ of homogenization buffer containing $50 \mathrm{mM}$ TEA/HCl, $\mathrm{pH} 7.4,10 \mathrm{mM}$

DTT, $1 \mathrm{mM}$ EDTA and complete ${ }^{\mathrm{TM}}$ protease inhibitor cocktail (Roche; Penzberg, Germany). For immunoprecipitation experiments PBS containing $1 \mathrm{mM}$ DTT and complete ${ }^{\mathrm{TM}}$ protease inhibitor cocktail was used. The cells were lysed by sonication. Cytosolic fractions were obtained by 
centrifugation for $30 \mathrm{~min}$ at $21000 \mathrm{~g}$ at $4{ }^{\circ} \mathrm{C}$. Protein concentrations were determined by the method of Bradford using bovine serum albumin as standard. For immunoprecipitation $1.5 \mathrm{mg}$ protein of the cytosol and $5 \mu \mathrm{g}$ anti-GFP antibody (Roche; Penzberg, Germany) were used. The method is described in detail in Haase et al. [6].

\subsection{SDS-PAGE, Coomassie Blue staining and immunoblot analysis}

For monitoring the purity of enzyme preparations and for the determination of apparent molecular masses of the purified enzyme, SDS-polyacrylamide gel electrophoresis was performed with $1 \mu \mathrm{g}$ purified enzyme in $10 \%$ slab gels, and proteins were stained with Coomassie Blue according to Kang et al. [11]. For immunoblotting, $1 \mu \mathrm{g}$ purified enzyme and $50 \mu \mathrm{g}$ cytosolic proteins were subjected to $10 \%$ SDS-PAGE and then transferred to nitrocellulose membranes. The following antibodies against the three NOsGC subunits were used for detection: $\alpha_{2}-84$ (1:750) [12], $\beta_{1}(1: 4000)$ and $\alpha_{1}$ (1:5000) (both Sigma Aldrich; Munich, Germany). The method is described in detail in Haase et al. [6].

\subsection{Purification of NOsGC}

All purification steps were performed at $4{ }^{\circ} \mathrm{C}$. The cell pellet from $500 \mathrm{ml}$ of cell solution infected with the respective NOsGC subunits or conjoined NOsGC was homogenized by sonification in $30 \mathrm{ml}$ homogenization buffer containing $50 \mathrm{mM}$ TEA/HCl, $\mathrm{pH}$ 7.4, $10 \mathrm{mM}$ DTT, $1 \mathrm{mM}$ EDTA and complete ${ }^{\mathrm{TM}}$ protease inhibitor cocktail. Avidin (250 nM, IBA; Goettingen, Germany) was added to the homogenate and incubated for $30 \mathrm{~min}$ at for $4{ }^{\circ} \mathrm{C}$. The homogenate was centrifuged at $15000 \mathrm{~g}$ for $2 \mathrm{~h}$ and $30 \mathrm{ml}$ of the supernatant was collected. All 
chromatographic steps were performed on an Äkta purifier system (GE Healthcare; Munich, Germany). The supernatant was immediately applied to a $\operatorname{Strep}^{-T a c t i n}{ }^{\circledR} \operatorname{Superflow}^{\circledR}$ high capacity (4 ml volume, IBA; Goettingen, Germany) column (C 10/10 and adapter AC 10, GE Healthcare; Munich, Germany) at $1 \mathrm{ml} / \mathrm{min}$. The Strep purification was done using the Strep-tag ${ }^{\circledR}$ Protein Purification Buffer Set and according to manufactures protocol (IBA; Goettingen, Germany).

Fractions showing absorption at $430 \mathrm{~nm}$ (Soret-band) were pooled and applied immediately with a flow rate of $15 \mathrm{ml} / \mathrm{min}$ to a HiPrep 26/10 Desalting column (GE Healthcare; Munich, Germany) that was equilibrated $5 \mathrm{CV}$ with IEX-1 (50 mM TEA, $10 \mathrm{mM}$ DTT, $1 \mathrm{mM}$ Benzamidin, $\mathrm{pH} 8.0$ ) buffer before use. Elution was carried out with $2 \mathrm{CV}$ at $15 \mathrm{ml} / \mathrm{min}$ with IEX-1 buffer and fractionated in $1.0 \mathrm{ml}$.

Fractions showing absorption at $430 \mathrm{~nm}$ (Soret-band) were pooled and applied immediately with a flow rat of $2 \mathrm{ml} / \mathrm{min}$ to a Mono Q 5/50 GL column (GE Hethcare; Munich, Germany) that was equilibrated $10 \mathrm{CV}$ with IEX-1 buffer before use. The column was washed $(10 \mathrm{CV})$ at $2 \mathrm{ml} / \mathrm{min}$ with IEX-1. Elution was carried out with $10 \mathrm{CV}$ at $2 \mathrm{ml} / \mathrm{min}$ with a linear gradient running from zero to $100 \%$ IEX-2 buffer (50 mM TEA, $10 \mathrm{mM}$ DTT, $1 \mathrm{mM}$ Benzamidin, $1 \mathrm{M}$ $\mathrm{NaCl}, \mathrm{pH} 8.0)$ and fractionated in $0.5 \mathrm{ml}$.

Fractions showing absorption at $430 \mathrm{~nm}$ (Soret-band) were pooled and concentrated in centrifugal devices with a 30-kDa cut-off (Millipore; Schwalbach, Germany) to $0.5 \mathrm{ml}$. The concentrated purified enzyme was used for spectroscopic analysis (250 to $500 \mathrm{~nm}$ ), SDS-PAGE, analytical gelfiltration and diluted with $50 \mathrm{mM}$ TEA/HCl, $\mathrm{pH} 7.4$ containing $10 \mathrm{mM}$ DTT, $1 \mathrm{mM}$ EDTA, $0.05 \%$ BSA (w/v) and stored with $10 \%(\mathrm{v} / \mathrm{v})$ glycerol at $-80{ }^{\circ} \mathrm{C}$. 


\subsection{Analytical gel filtration}

$200 \mu \mathrm{g}$ of purified enzyme was applied with a flow rat of $0.3 \mathrm{ml} / \mathrm{min}$ to a HiLoad ${ }^{\mathrm{TM}} 16 / 60$ Superdex ${ }^{\text {TM}} 200$ prep grade column (GE Hethcare; Munich, Germany) that was equilibrated 3 CV with gel filtration buffer ( $50 \mathrm{mM}$ TEA, $250 \mathrm{mM} \mathrm{NaCl}$; $\mathrm{pH} 8.0)$ before use. Elution was carried out with $1.5 \mathrm{CV}$ at $0.3 \mathrm{ml} / \mathrm{min}$ with gel filtration buffer and fractionated in $1 \mathrm{ml}$ aliquots. Fractions showing absorption at $430 \mathrm{~nm}$ (Soret-band) were pooled, concentrated in centrifugal devices with a 30-kDa cut-off and analyzed by Western blot.

\subsection{Guanylyl Cyclase Activity Assay}

The determination of NOsGC enzyme activity of Sf9 cytosol or purified protein (10 ng/assay tube) was described in detail in Haase et al. [6]. Basal enzyme activity measurements were performed in the absence of $\mathrm{NO}$ or NOsGC activators. NO stimulated measurements were performed in the presence of $100 \mu \mathrm{M}$ of the NO donor DEA/NO and $\mathrm{NO} / \mathrm{YC}-1$ stimulated measurements were performed in the presence of both $100 \mu \mathrm{M} \mathrm{DEA} / \mathrm{NO}$ and $100 \mu \mathrm{M}$ YC-1. Heme independent activators (cinaciguat or ataciguat) were tested in a concentration of $10 \mu \mathrm{M}$ in the presence and absence of $10 \mu \mathrm{M}$ ODQ.

\subsection{Statistical analysis}

The results are expressed as means \pm SEM. of at least three experiments using different animals. All results were controlled for their statistical significance by Student's t-test. A value of $\mathrm{p}<0.05$ was considered to be statistically significant. 


\section{Results}

Recombinant expression of a functional NOsGC enzyme in a baculovirus/Sf9 system requires the co-expression of $\alpha$ and $\beta$ subunits. NOsGC subunits also form homodimeric complexes when they are co-expressed in Sf9 cells [5]. Immunoprecipitation experiments (Fig. 1) confirmed the data from Zabel et al. [5] that $\beta_{1}$ and $\alpha_{1}$ have the ability to form homodimers. In addition our data show that the $\alpha_{2}$ subunit also forms homodimers. Thus co-expression of $\alpha$ and $\beta$ subunits will always lead to a mixture of active NOsGC heterodimers and catalytically inactive NOsGC homodimers with other potential functions [7-9]. To isolate pure heterodimeric enzymes, we cloned constructs that guarantee a 1:1 stochiometry between $\alpha$ and $\beta$ subunits and rule out the presence of homodimers. Studies in our lab on fluorescent labeled NOsGC subunits [13] have shown that fluorescent proteins tagged to the carboxy-terminus of the $\beta_{1}$ subunit and aminoterminus of the $\alpha$ subunit are close enough to each other to allow energy transfer (distance 10$100 \AA$ ). Based on these data, we directly fused the carboxy-terminus of the $\beta_{1}$ subunit with the amino-terminus of the $\alpha$ subunit without a fluorescent protein as a linker as in Haase et al. [13] and established a direct $\beta_{1} \alpha_{1}$ fusion construct which we designated "conjoined NOsGC". Conjoined NOsGC expression yielded an active and NO sensitive GC enzyme in crude Sf9 cell cytosolic fractions (Fig. 2). Guanylyl cyclase activity was measured under basal conditions, activation with $\mathrm{NO}$ and activation with the combination of $\mathrm{NO}$ and $\mathrm{YC}-1$ as in previous similar studies [14-15]. There was a trend towards increased guanylyl cyclase activity for the conjoined versus the heterodimeric NOsGC under all experimental conditions that did not reach statistical significance $(\mathrm{p}<0.05)$ (Fig. 2). For further comparison of conjoined NOsGC and heterodimeric NOsGC we used a STREP (S) tag II [16] affinity purification. Coomassie Blue-stained SDSPAGE analysis of purified co-expressed NOsGC isoforms and conjoined NOsGC are shown in 
Fig. 3. The two detected signals with molecular mass of 80 and $72 \mathrm{kDa}$ for the co-expressed NOsGC isoforms correspond to the expected molecular mass predicted from their amino acid sequences $\left(79,6 \mathrm{kDa}\right.$ for $\alpha_{1} \mathrm{~S}, 78,6 \mathrm{kDa}$ for $\alpha_{1}, 83,8 \mathrm{kDa}$ for $\alpha_{2} \mathrm{~S}, 71,4 \mathrm{kDa}$ for $\beta_{1} \mathrm{~S}$ and 70,4 $\mathrm{kDa}$ for $\beta_{1}$ ). For the conjoined NOsGC's one signal could be detected with a molecular mass of approximately $150 \mathrm{kDa}$, which is close to the estimated molecular mass of $\beta_{1} \alpha_{1} \mathrm{~S}$ and $\beta_{1} \alpha_{2} \mathrm{~S}$ conjoined NOsGC $(149,1 \mathrm{kDa}$ and $158,6 \mathrm{kDa})$. STREP tag II purification of the co-expressed NOsGC isoforms with carboxy-terminally tagged $\beta_{1}$ subunits showed an unequal ratio of NOsGC subunits with a shift to the $\beta_{1}$ subunit (Fig.3 A) indicating the purification of substantial amounts of $\beta_{1}$ homodimers besides heterodimeric enzyme. Purification using the carboxy-terminally tagged $\alpha$ subunit co-expressed with a non-tagged $\beta_{1}$ subunit led to an apparent $1: 1$ ratio of $\alpha$ and $\beta$ subunits (Fig. 3B). Spectroscopic analysis of the purified enzymes (Fig. 4) revealed absorption maxima at $430 \mathrm{~nm}$ in the absence and $400 \mathrm{~nm}$ in the presence of the NO Donor DEA/NO $(100 \mu \mathrm{M})$. The maxima of conjoined NOsGC's (Fig. 4C and 4D) were identical to the respective co-expressed NOsGC isoforms (Fig. 4A and 4B). The ratio of the absorption of $430 \mathrm{~nm}$ to $280 \mathrm{~nm}$ for all purified NOsGC variants was not significantly different.

To analyze whether the conjoined NOsGC's exist as monomers and correspond in their native molecular mass to the co-expressed NOsGC heterodimer, we did a comparison of analytical gel filtration. The elution profiles were recorded at $430 \mathrm{~nm}$. Conjoined NOsGC's and co-expressed NOsGC isoforms showed a peak at the same elution volume indicating similar molecular masses (Fig. 5 upper panel). Western Blot analysis using antibodies directed against the NOsGC subunits were done to ensure the identity and integrity of the eluted sample (Fig. 5 lower panel).

Guanylyl cyclase activity of the purified enzyme was measured under basal conditions, in the presence of $\mathrm{NO}(100 \mu \mathrm{M}$ DEA/NO) and in the presence of additional YC-1 $(100 \mu \mathrm{M})$ to analyze 
the properties of the enzyme preparations (Fig. 6). Guanylyl cyclase activity under NO and $\mathrm{NO} / \mathrm{YC}-1$ stimulated conditions was not different between conjoined NOsGC and the heterodimeric form. Only basal activity was significantly increased in conjoined NOsGC ( $p<$ $0.05)$.

To compare the kinetic properties of the conjoined NOsGC's with the respective heterodimeric NOsGC isoforms, cGMP formation was determined in the presence of increasing GTP concentrations. The Lineweaver-Burk plot of the data under basal conditions (Fig. 7, left) and the presence of $100 \mu \mathrm{M}$ DEA/NO (Fig. 7, right) revealed that the kinetic data (Fig. 7, tables) showed no significant differences between the conjoined NOsGC's and the respective heterodimeric NOsGC isoforms.

Concentration response experiments were done using the NO donor DEA/NO (Fig. 8). Although the $\mathrm{EC}_{50}$ values for DEA/NO showed no significant differences between the conjoined NOsGC's and the respective heterodimeric NOsGC isoforms, there was a trend towards an increased $\mathrm{EC}_{50}$ value (lower affinity) for heterodimeric $\alpha_{1} \mathrm{~S} / \beta_{1}$.

Guanylyl cyclase assays were also performed in the presence of the heme independent NOsGC activators cinaciguat (BAY 58-2667) (Fig. 9 left) and ataciguat (HMR 1766) (Fig. 9 right). In the presence of cinaciguat and ataciguat (Fig. 9) the purified heterodimeric $\alpha_{1} S / \beta_{1}$ isoform and $\beta_{1} \alpha_{1} S$ conjoined NOsGC showed an expected increase in enzyme activity. Treatment with ODQ led to a further expected activation by cinaciguat and ataciguat for the $\alpha_{1} S / \beta_{1}$ isoform and $\beta_{1} \alpha_{1} S$ conjoined NOsGC. In contrast, the purified heterodimeric $\alpha_{2} S / \beta_{1}$ isoform and conjoined $\beta_{1} \alpha_{2} \mathrm{~S}$ NOsGC were just marginally activated by cinaciguat and ataciguat (Fig. 9). The difference in activation by ciguates between the $\alpha_{2}$ containing and $\alpha_{1}$ containing forms was statistically significant $(\mathrm{p}<0.05)$. Treatment with ODQ did not change the isoform specific difference in activation by ciguates between the the $\alpha_{2}$ containing and $\alpha_{1}$ containing forms. 
To compare the kinetic properties of the enzyme isoforms in the presence of cinaciguat and ODQ, cGMP formation was determined in the presence of increasing GTP concentrations and plotted according to Lineweaver-Burk (Fig. 10). Cinaciguat increased the $\mathrm{V}_{\max }$ of the heterodimeric $\alpha_{1} S / \beta_{1}$ isoform significantly $(\mathrm{p}<0.05)$, while there was no significant increase for the $\alpha_{2} \mathrm{~S} / \beta_{1}$ isoform. The $\mathrm{K}_{\mathrm{m}}$ values of both isoforms showed a significant decrease in the presence of cinaciguat $(\mathrm{p}<0.05)$. Measurement of $\mathrm{EC}_{50}$ values for the activation by cinaciguat confirmed the data for the $\alpha_{1} \mathrm{~S} / \beta_{1}$ isoform [17], while no $\mathrm{EC}_{50}$ value could be detected for the $\alpha_{2} \mathrm{~S} / \beta_{1}$ isoform (data not shown). 


\section{Discussion}

Since 1879 until now the drug of choice for the treatment of acute angina pectoris is and has been glycerol trinitrate [18]. The receptors for this drug in humans are both NO sensitive guanylyl cyclase isoforms $\alpha_{1} / \beta_{1}$ and $\alpha_{2} / \beta_{1}$. No difference has so far been detected in the pharmacological properties of both purified enzyme isoforms [4]. In the present paper we provide the first evidence that ciguat-activators a novel non-NO-releasing drug group activate the $\alpha_{1} / \beta_{1}$ isoform of NOsGC much more effectively than the $\alpha_{2} / \beta_{1}$ subtype. This is a surprising finding as the ciguat-activators bind to the heme NO binding domain of the $\beta_{1}$ subunit [17] which is common to both isoforms. It would have been conceivable that a different degree of heme content or oxidation in $\alpha_{1} / \beta_{1}$ and $\alpha_{2} / \beta_{1}$ isoforms explains the difference. But our data showing identical heme content between both isoforms (see Fig. 4) and the preserved difference with respect to ciguate activation in the presence of the heme oxidizing substance ODQ argue against this idea. Thus the difference in ciguat-activation between both isoforms seems to lie in the intramolecular signal transduction that converts binding of the ciguat-activators into a conformational changes in the catalytic region leading to an increase in $V_{\max }$ for the $\alpha_{1} / \beta_{1}$ isoforms. A cinaciguat-analogue has been shown to bind to tyrosine 371 of the $\alpha_{1}$ subunit [17]. It is conceivable that this tyrosine in the $\alpha_{1}$ subunit and the lack of a homologous tyrosine in the $\alpha_{2}$ subunits contributes to the isoform specific $V_{\max }$ increase in the $\alpha_{1} / \beta_{1}$ isoform. However, the specificity is not absolute since similar to NO the affinity towards the substrate GTP is increased for both isoforms in the presence of cinaciguat as shown by decreased $\mathrm{K}_{\mathrm{m}}$ values. We would like to emphasize that an isoform specific $\mathrm{V}_{\max }$ increase seen with purified enzyme preparations is not necessarily linked to isoform specificity in vivo. Local substrate concentrations, differing subcellular localization of both isoforms or protein interactions may all lead to differences 
between isolated enzymes and the intact cell situation. The selectivity of ciguates for the $\alpha_{1} / \beta_{1}$ isoform and its pharmacological relevance could and should be further analyzed in $\alpha_{1} \mathrm{KO}$ mice [19-22].

Given that the potentially isoform specific ciguat-activators are being developed clinically, it seems very important to study the individual roles and specialized functions of the different isoforms. Knockout animals of the different $\alpha$ subunits have provided important insights in the effects of selective abrogation of one isoform [19-22]. It did not seem feasible so far to do the complementary reverse experiment namely selective overexpression of one isoform in a transgenic mouse model. First, co-expression of $\alpha$ and $\beta$ subunits with similar levels of expression is technically demanding. Second, even if successful it is unclear to what extent overexpressed single $\alpha$ and $\beta$ subunits interfere with the respective other enzyme isoform. The knockout animals clearly demonstrate interdependence of the stability of the $\alpha$ and $\beta$ subunits [19]. Third in a transgenic overexpression model homodimers of isolated $\alpha$ or isolated $\beta$ subunits will form in addition to heterodimers and there is recent evidence to suggest that they have a separate function from cGMP signaling: It has been suggested that the $\beta_{1}$ subunit is a multifunctional protein that regulates chromatin condensation and cell cycle progression in addition to being an obligate component of functional NOsGC-heterodimers [9]. Published data also indicates that the $\alpha_{1}$ subunit acts in prostate cancer via a novel pathway that does not depend on the $\beta_{1}$ subunit [7] and is especially important in androgen-independent growth of prostate cancer cells [8].

The genes encoding the $\alpha_{1}$ and $\beta_{1}$ subunits are colocalized in all species analyzed so far [2325] and have a striking tandem arrangement in medaka fish where the last exon of the $\alpha_{1}$ subunit and first exon of the $\beta_{1}$ subunit are separated by less than 1000 base pairs [26]. Currently it is unclear what selection pressure preserves this peculiar genomic colocalization throughout 
evolution. Although both subunit genes have stayed very close in the phylogenetic tree of animals there is no species known where the genes actually fused to form one polypeptide chain as in other nucleotide cyclases e.g. mammalian adenylyl cyclase. It would have been conceivable that structural requirements preclude such a gene fusion. But as we show in the current paper this is not the case. We hypothesize that the heterodimeric nature of the enzyme has other important functions that are vital for organisms. First, it allows a function of either single $\alpha$ subunits or single $\beta$ subunits discussed above [7-9]. A second possibility is that regulating expression of different mRNAs and regulating stability of different subunits allows better fine tuning of the NO sensing enzyme: We have recently given further support to the idea initially proposed by Zabel et al. [5] that regulation of NOsGC activity in vivo might involve changes in the extent of heterodimerization [6].

We show for the first time isoform specific activation of NOsGC by ciguates using purified protein and provide tools to investigate the two different isoforms in two separate entities in overexpression experiments with no interference by single subunits or homodimers. If experiments in transgenic animals are encouraging conjoined NOsGC constructs may also enable experiments directed towards therapeutic overexpression of NOsGC in gene therapy. 


\section{Acknowledgments}

We thank Anja Stieler and Ines Thomsen for their excellent technical assistance. 


\section{Footnotes}

\footnotetext{
${ }^{1}$ ResearcherID: A-1701-2010

${ }^{2}$ ResearcherID: A-4297-2010

${ }^{3}$ ResearcherID: D-5327-2009

${ }^{4}$ ResearcherID: A-2551-2010
} 


\section{Abbreviations}

BSA, bovine serum albumin

CFP, cyan fluorescent protein

$\mathrm{CV}$, column volume

DTT, dithiothreitol;

GFP, green fluorescent protein

NO, nitric oxide

NOsGC, NO sensitive guanylyl cyclase

PAGE, polyacrylamide gel electrophoresis

PBS, phosphate buffered saline

SDS, sodium dodecyl sulfate

S, STREP tag II

TEA, triethanolamine

YFP, yellow fluorescent protein 


\section{References}

[1] Garthwaite J. Concepts of neural nitric oxide-mediated transmission. Eur J Neurosci $2008 ; 27: 2783-802$.

[2] Bryan NS, Bian K, Murad F. Discovery of the nitric oxide signaling pathway and targets for drug development. Front Biosci 2009;14:1-18.

[3] Russwurm M, Wittau N, Koesling D. Guanylyl cyclase/PSD-95 interaction: targeting of the nitric oxide-sensitive alpha2beta1 guanylyl cyclase to synaptic membranes. J Biol Chem 2001;276:44647-52.

[4] Russwurm M, Behrends S, Harteneck C, Koesling D. Functional properties of a naturally occurring isoform of soluble guanylyl cyclase. Biochem J 1998;335 ( Pt 1):125-30.

[5] Zabel U, Hausler C, Weeger M, Schmidt HH. Homodimerization of soluble guanylyl cyclase subunits. Dimerization analysis using a glutathione s-transferase affinity tag. J Biol Chem 1999;274:18149-52.

[6] Haase N, Haase T, Seeanner M, Behrends S. Nitric oxide sensitive guanylyl cyclase activity decreases during cerebral postnatal development because of a reduction in heterodimerization. J Neurochem 2010;112:542-51.

[7] Cai C, Chen SY, Zheng Z, Omwancha J, Lin MF, Balk SP, et al. Androgen regulation of soluble guanylyl cyclasealpha1 mediates prostate cancer cell proliferation. Oncogene 2007;26:1606-15.

[8] Hsieh CL, Cai C, Giwa A, Bivins A, Chen SY, Sabry D, et al. Expression of a hyperactive 
androgen receptor leads to androgen-independent growth of prostate cancer cells. J Mol Endocrinol 2008;41:13-23.

[9] Pifarre P, Baltrons MA, Foldi I, Garcia A. NO-sensitive guanylyl cyclase betal subunit is peripherally associated to chromosomes during mitosis. Novel role in chromatin condensation and cell cycle progression. Int J Biochem Cell Biol 2009;41:1719-30.

[10] Koglin M, Behrends S. Cloning and functional expression of the rat alpha(2) subunit of soluble guanylyl cyclase. Biochim Biophys Acta 2000;1494:286-9.

[11] Kang D, Gho YS, Suh M, Kang C. Highly sensitive and fast protein detection with Coomassie brilliant blue in sodium dodecyl sulfate-polyacrylamide gel electrophoresis. Bull Korean Chem Soc 2002;23:1511-2.

[12] Bamberger AM, Koglin M, Kempfert J, Loning T, Scholz H, Behrends S. Expression and tissue localization of soluble guanylyl cyclase in the human placenta using novel antibodies directed against the alpha(2) subunit. J Clin Endocrinol Metab 2001;86:909-12.

[13] Haase T, Haase N, Krähling J, Behrends S. Fluorescent Fusion Proteins of Soluble Guanylyl Cyclase Indicate Proximity of the Heme Nitric Oxide Domain and Catalytic Domain. PLoS One 2010; under revision.

[14] Koglin M, Vehse K, Budaeus L, Scholz H, Behrends S. Nitric oxide activates the beta 2 subunit of soluble guanylyl cyclase in the absence of a second subunit. J Biol Chem 2001;276:30737-43.

[15] Koglin M, Behrends S. A functional domain of the alpha1 subunit of soluble guanylyl cyclase is necessary for activation of the enzyme by nitric oxide and YC-1 but is not involved in 
heme binding. J Biol Chem 2003;278:12590-7.

[16] Schmidt TG, Skerra A. The Strep-tag system for one-step purification and high-affinity detection or capturing of proteins. Nat Protoc 2007;2:1528-35.

[17] Stasch JP, Schmidt P, Alonso-Alija C, Apeler H, Dembowsky K, Haerter M, et al. NOand haem-independent activation of soluble guanylyl cyclase: molecular basis and cardiovascular implications of a new pharmacological principle. Br J Pharmacol 2002;136:773-83.

[18] Murrell W. Nitro-glycerine as a remedy for angina pectoris. Lancet 1879;1:80, 113, 51, 225.

[19] Mergia E, Friebe A, Dangel O, Russwurm M, Koesling D. Spare guanylyl cyclase NO receptors ensure high NO sensitivity in the vascular system. J Clin Invest 2006;116:1731-7.

[20] Haghikia A, Mergia E, Friebe A, Eysel UT, Koesling D, Mittmann T. Long-term potentiation in the visual cortex requires both nitric oxide receptor guanylyl cyclases. J Neurosci 2007;27:818-23.

[21] Buys ES, Sips P, Vermeersch P, Raher MJ, Rogge E, Ichinose F, et al. Gender-specific hypertension and responsiveness to nitric oxide in sGCalphal knockout mice. Cardiovasc Res 2008;79:179-86.

[22] Atochin DN, Yuzawa I, Li Q, Rauwerdink KM, Malhotra R, Chang J, et al. Soluble Guanylate Cyclase \{alpha 1 \{beta 1 Limits Stroke Size and Attenuates Neurological Injury. Stroke 2010;41:1815-9.

[23] Giuili G, Roechel N, Scholl U, Mattei MG, Guellaen G. Colocalization of the genes coding for the alpha 3 and beta 3 subunits of soluble guanylyl cyclase to human chromosome 4 at 
q31.3-q33. Hum Genet 1993;91:257-60.

[24] Azam M, Gupta G, Chen W, Wellington S, Warburton D, Danziger RS. Genetic mapping of soluble guanylyl cyclase genes: implications for linkage to blood pressure in the Dahl rat. Hypertension 1998;32:149-54.

[25] Sharina IG, Krumenacker JS, Martin E, Murad F. Genomic organization of alpha1 and beta1 subunits of the mammalian soluble guanylyl cyclase genes. Proc Natl Acad Sci U S A 2000;97:10878-83.

[26] Mikami T, Kusakabe T, Suzuki N. Tandem organization of medaka fish soluble guanylyl cyclase alpha1 and beta1 subunit genes. Implications for coordinated transcription of two subunit genes. J Biol Chem 1999;274:18567-73. 


\section{Legends of figures}

Fig. 1. Homodimerization of NOsGC subunits. Cytosolic fractions of $\mathrm{Sf} 9$ cells coexpressing YFP-tagged and nontagged NOsGC subunits were used for immunoprecipitation with an antibody against YFP. The precipitates were analyzed by Western blot using antibodies against $\beta_{1}(\mathrm{~A}), \alpha_{1}(\mathrm{~B})$ and $\alpha_{2}(\mathrm{C})$ subunit of NOsGC.

Fig. 2. Comparison of NOsGC activity in cytosolic fractions of Sf9 cells coexpressing the $\alpha$ and $\beta$ subunits and expressing the conjoined NOsGC. Guanylyl cyclase activity was measured under basal conditions (black columns), in the presence of $100 \mu \mathrm{M} \mathrm{DEA} / \mathrm{NO}$ (white columns) and in the presence of additional $100 \mu \mathrm{M}$ YC-1 (gray columns). Data are expressed as means \pm S.E.M. $(n=4)$.

Fig. 3. SDS-PAGE analysis of purified NOsGC variants $\left(A-\alpha_{1} / \beta_{1} S ; B-\alpha_{1} S / \beta_{1}\right.$ and $\boldsymbol{\beta}_{1} \boldsymbol{\alpha}_{1} \mathbf{S} ; \mathbf{C}-\boldsymbol{\alpha}_{2} \mathbf{S} / \boldsymbol{\beta}_{1}$ and $\left.\boldsymbol{\beta}_{1} \boldsymbol{\alpha}_{2} \mathbf{S}\right) .1 \mu \mathrm{g}$ of purified enzyme (S indicates STREP tag) was electrophoreretically separated by SDS-PAGE and stained with Coomassie Blue (a representative gel is shown).

Fig. 4. Spectroscopic analysis of purified guanylyl cyclase enzyme complexes $\left(\mathrm{A} \boldsymbol{\alpha}_{1} \mathrm{~S} / \boldsymbol{\beta}_{1}\right.$; B $\left.\boldsymbol{\alpha}_{2} S / \boldsymbol{\beta}_{1} ; C \boldsymbol{\beta}_{1} \alpha_{1} S ; D \boldsymbol{\beta}_{1} \alpha_{2} S\right)$. Spectroscopic analysis shows relative absorption values at basal (solid line) or NO-stimulated (100 M DEA/NO, dotted line) conditions. The ratio of the absorption at $432 \mathrm{~nm}$ to $280 \mathrm{~nm}$ was $0.81 \pm 0.13$ for $\alpha_{1} \mathrm{~S} / \beta_{1}, 0.82 \pm 0.10$ for $\beta_{1} \alpha_{1} \mathrm{~S}, 0.92 \pm 0.04$ for $\alpha_{2} \mathrm{~S} / \beta_{1}$, and $0.90 \pm 0.05$ for $\beta_{1} \alpha_{2} \mathrm{~S}$ (S indicates STREP tag) 
Fig. 5. Characterization of the purified NOsGC variants by gel chromatography and Western blot analysis. Elution profiles of NOsGC variants are shown for gel filtration column (upper panel). The respective peak fractions were pooled, concentrated and $1 \mu \mathrm{g}$ of protein was used for Western blot analysis using antibodies against $\alpha_{1}, \alpha_{2}$ and $\beta_{1}$ subunit of NOsGC (lower panel, a representative blot is shown).

Fig. 6. Comparison of NOsGC activity of purified NOsGC heterodimer and conjoined NOsGC. Guanylyl cyclase activity was measured under basal conditions (black columns), in the presence of $100 \mu \mathrm{M}$ DEA/NO (white columns) and in the presence of additional $100 \mu \mathrm{M} \mathrm{YC}-1$ (gray columns). Data are expressed as means $\pm \operatorname{SEM}(n=3)$.

Fig. 7. Double reciprocal Linewaever-Burk plot for substrate dependence of respective purified NOsGC variants (see figure key). Substrate dependence was measured in a range from 0.01 to $1 \mathrm{mM}$ under basal conditions (left) and in the presence of $100 \mu \mathrm{M} \mathrm{DEA} / \mathrm{NO}$ (right). In the tables below the diagram the $V_{\max }$ and $K_{m}$ values are shown. Data represent means of at least three independent experiments performed in duplicate \pm S.E.M.

Fig. 8. Concentration-dependent effect of of DEA/NO on purified guanylyl cyclase activity. Dose-response curve of $\alpha_{1} S / \beta_{1}$ (closed circle), $\beta_{1} \alpha_{1} S$ (open circles), $\alpha_{2} S / \beta_{1}$ (closed triangles) and $\beta_{1} \alpha_{2} \mathrm{~S}$ (open triangles) were measured in a range of $0.1 \mathrm{nM}$ to $1 \mathrm{mM} \mathrm{DEA} / \mathrm{NO}$. $\mathrm{EC}_{50}$ values are given in the table. Data are expressed as means \pm S.E.M. $(\mathrm{n}=3)$.

Fig. 9. Guanylyl cyclase activity of the purified respective NOsGC enzyme complexes in the presence of cinaciguat (left) and ataciguat (right). Guanylyl cyclase activity was measured 
under basal conditions (black columns), in the presence of $10 \mu \mathrm{M}$ cinaciguat or $10 \mu \mathrm{M}$ ataciguat (grey columns) and in the presence of additional $10 \mu \mathrm{M}$ ODQ (striped columns). Data are expressed as means $\pm \operatorname{SEM}\left(n=3,{ }^{*} \mathrm{p}<0.05 \alpha_{1} \mathrm{~S} / \beta_{1}\right.$ vs $\alpha_{2} \mathrm{~S} / \beta_{1} ;{ }^{\$} \mathrm{p}<0.05 \beta_{1} \alpha_{1} \mathrm{~S}$ vs $\beta_{1} \alpha_{2} \mathrm{~S} ;{ }^{\#} \mathrm{p}<0.05$ $\alpha_{1} \mathrm{~S} / \beta_{1}$ vs $\alpha_{2} \mathrm{~S} / \beta_{1} ;{ }^{\S} \mathrm{p}<0.05 \beta_{1} \alpha_{1} \mathrm{~S}$ vs $\left.\beta_{1} \alpha_{2} \mathrm{~S}\right)$.

Fig. 10. Double reciprocal Linewaever-Burk plot for substrate dependence of respective purified sGC variants (see figure key) in the presence of $10 \mu \mathrm{M} O D Q$ and $10 \mu \mathrm{M}$ cinaciguat. Substrate dependence was measured in a range from 0.01 to $1 \mathrm{mM}$. Data represent means of at least three independent experiments performed in duplicate \pm S.E.M. $(n=3$, statistical significance for $\mathrm{V}_{\max }$ and $\left.\mathrm{K}_{\mathrm{m}}: * \mathrm{p}<0.05 \alpha_{1} \mathrm{~S} / \beta_{1} \mathrm{vs} \alpha_{2} \mathrm{~S} / \beta_{1}\right)$. 

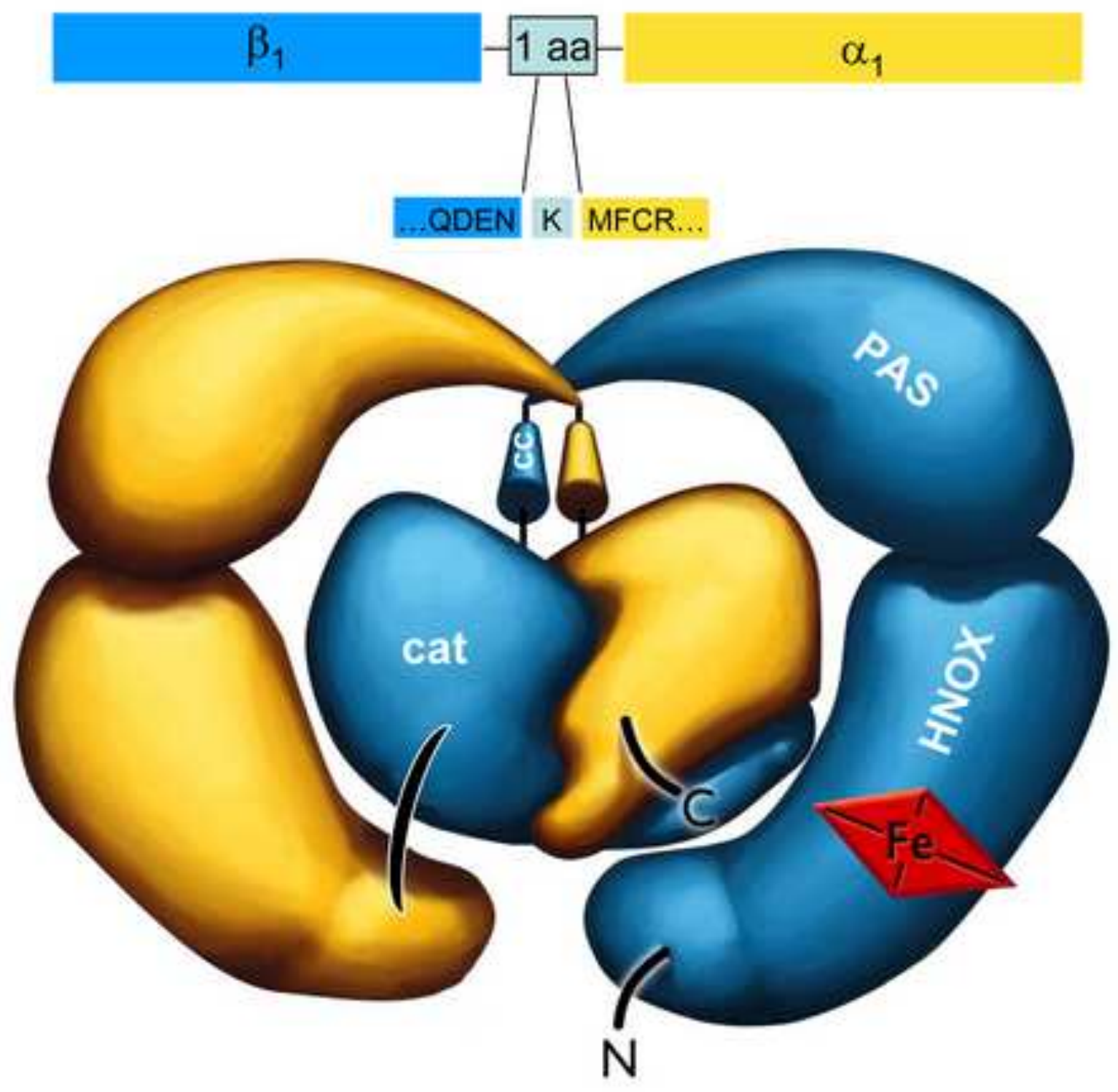

rage $2 y$ or $3 y$ 
0

$\left.d \exists \lambda^{2} n\right|^{z_{n}}$

$\mathbf{m}$

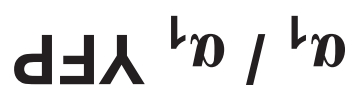

논

$g \mu_{1} d / g$

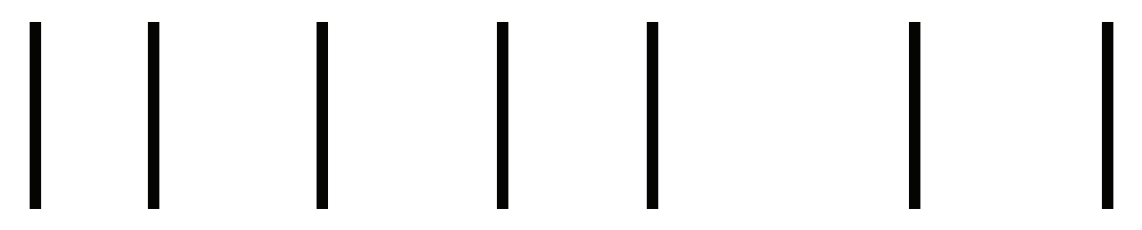

$$
\begin{aligned}
& \text { ํํำำ ㅇํำ }
\end{aligned}
$$



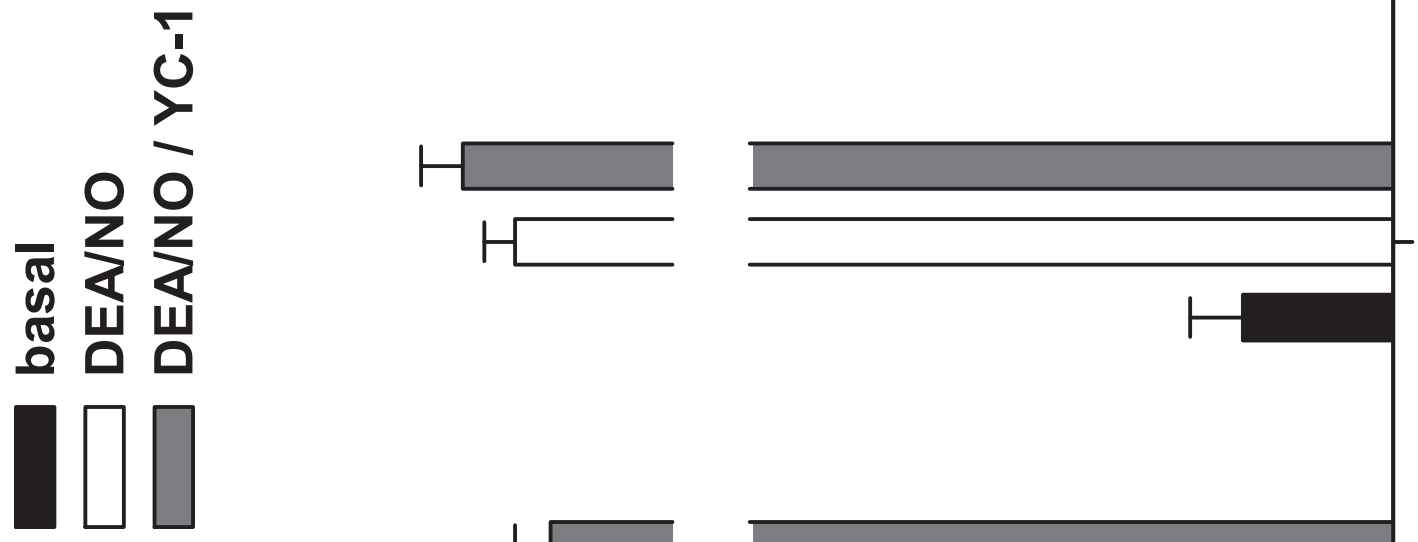

$3^{N}$

ต
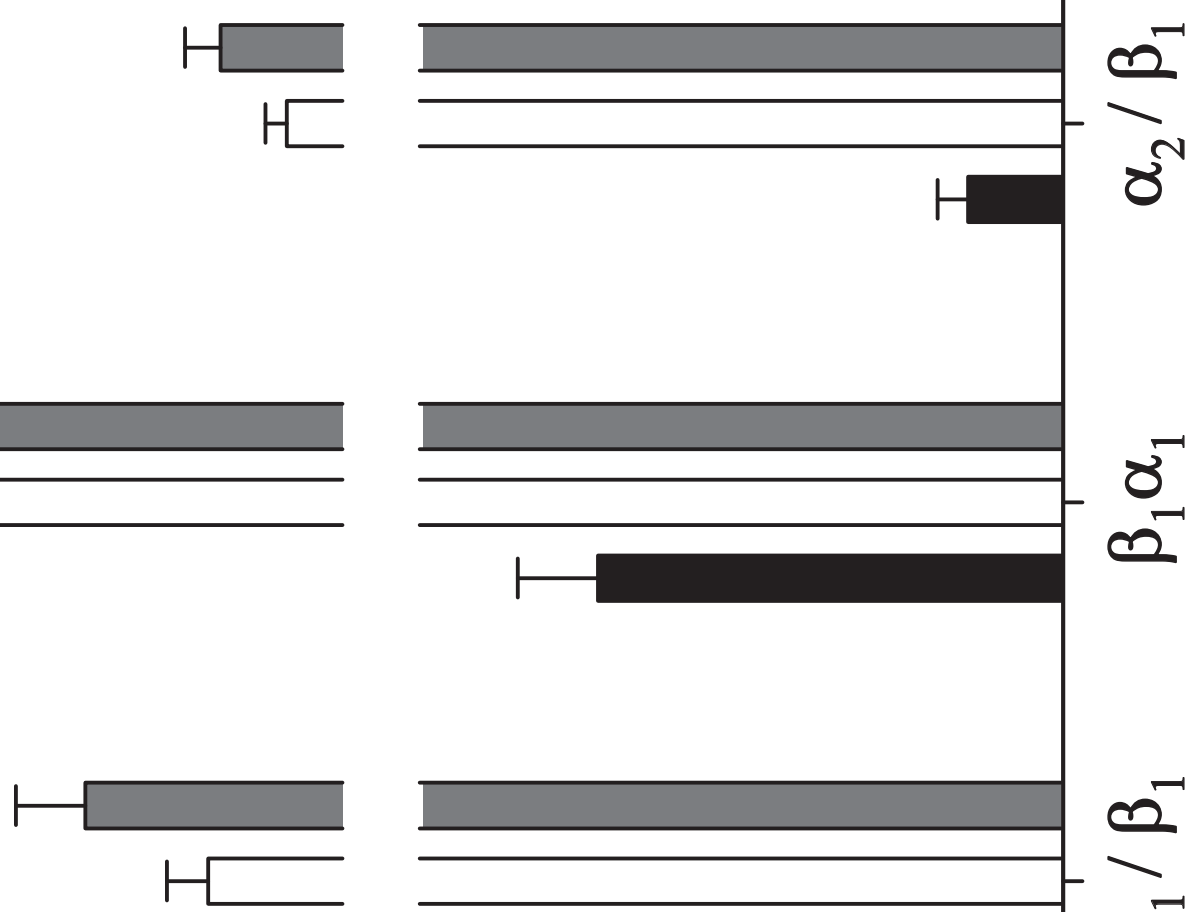

L
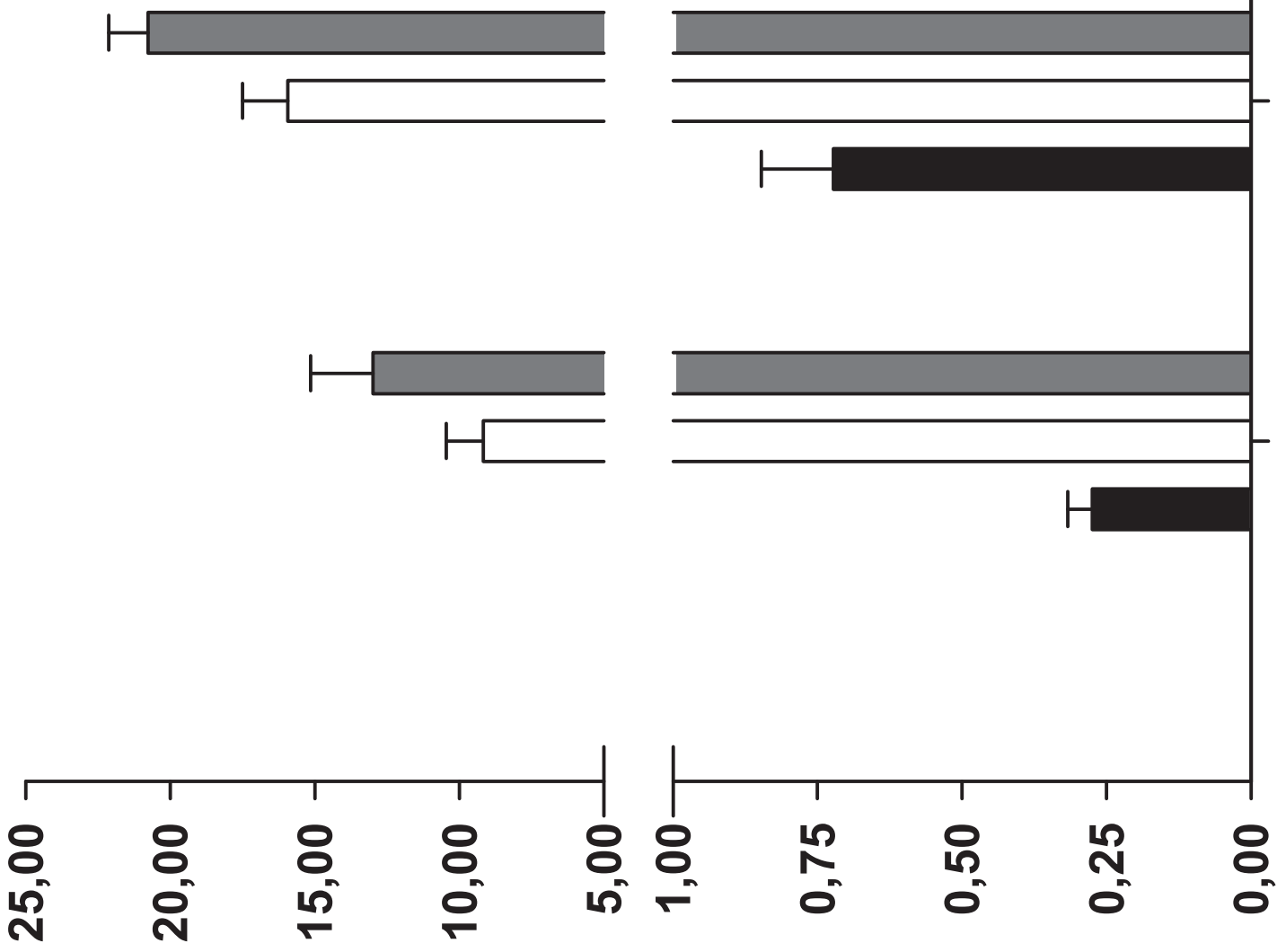

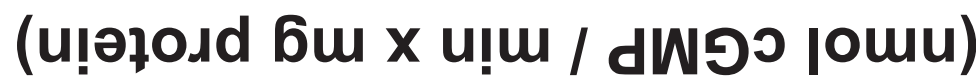

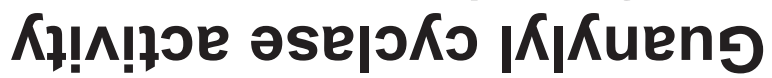


$s^{2} d^{\prime} d$

$\operatorname{s} / s^{2}$
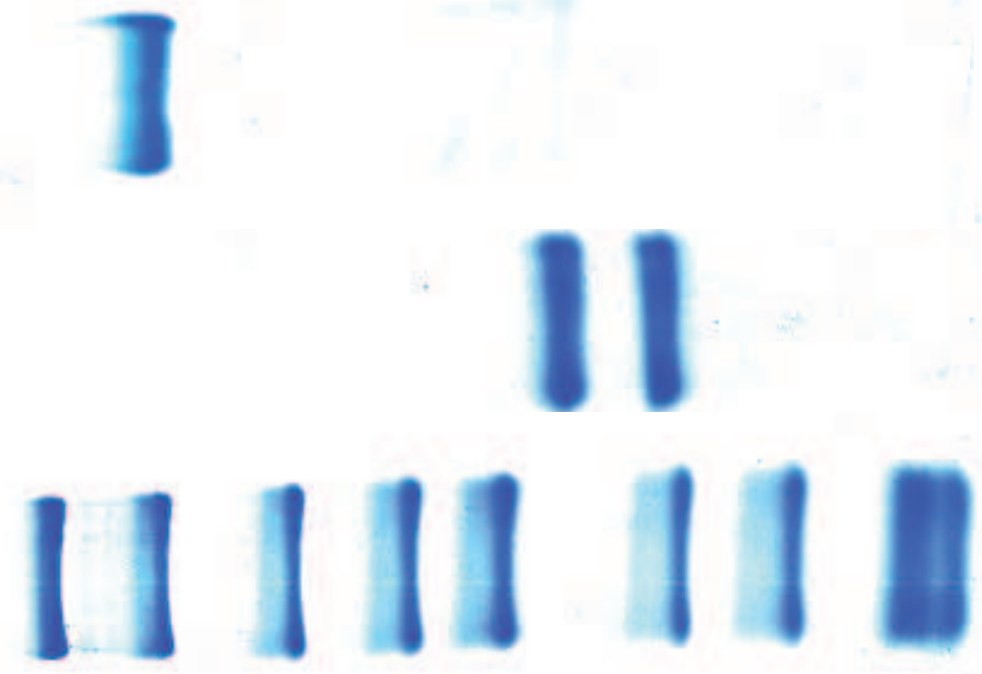

윳요 옹 용

28 :

$\boldsymbol{m}$
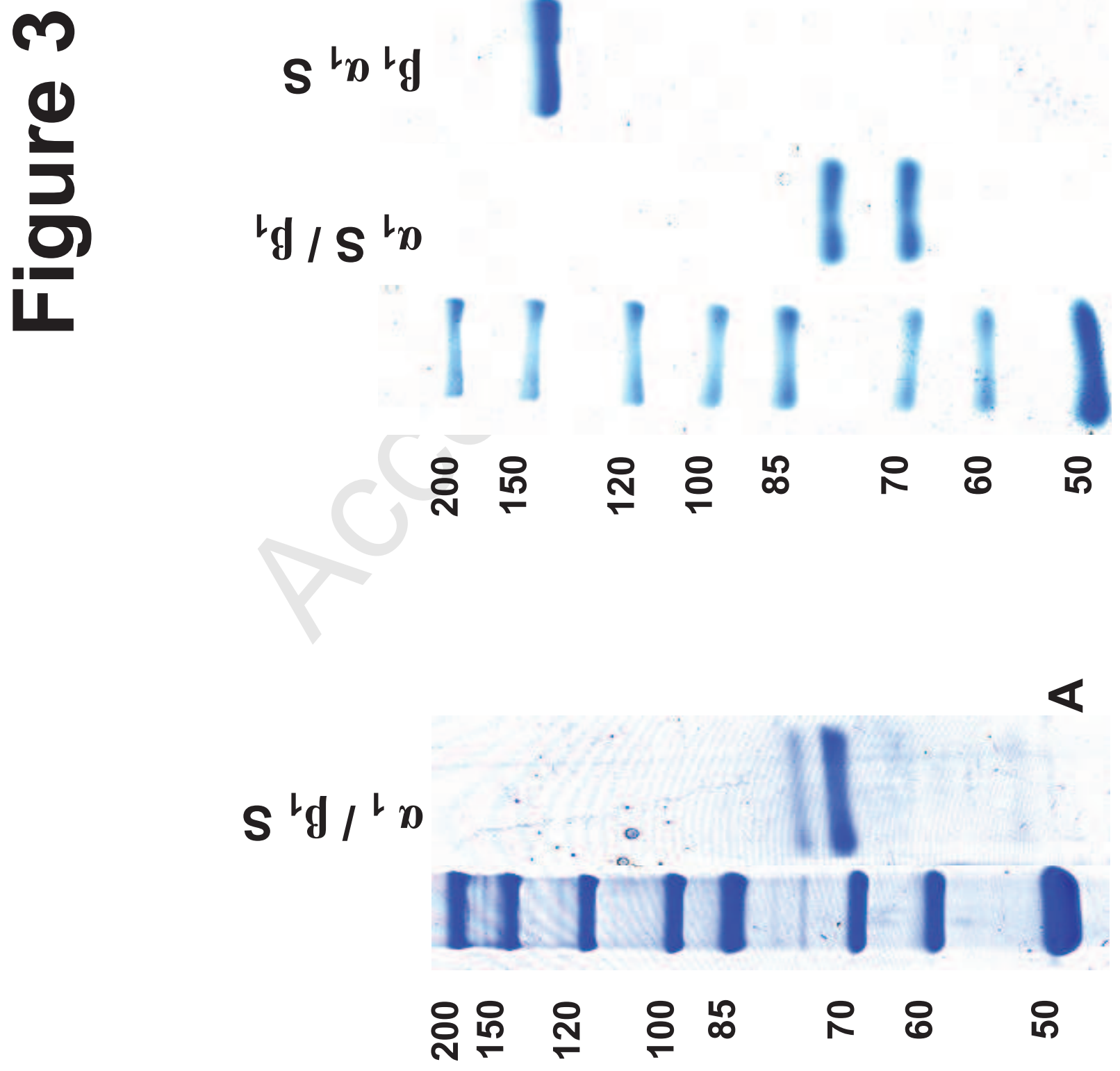


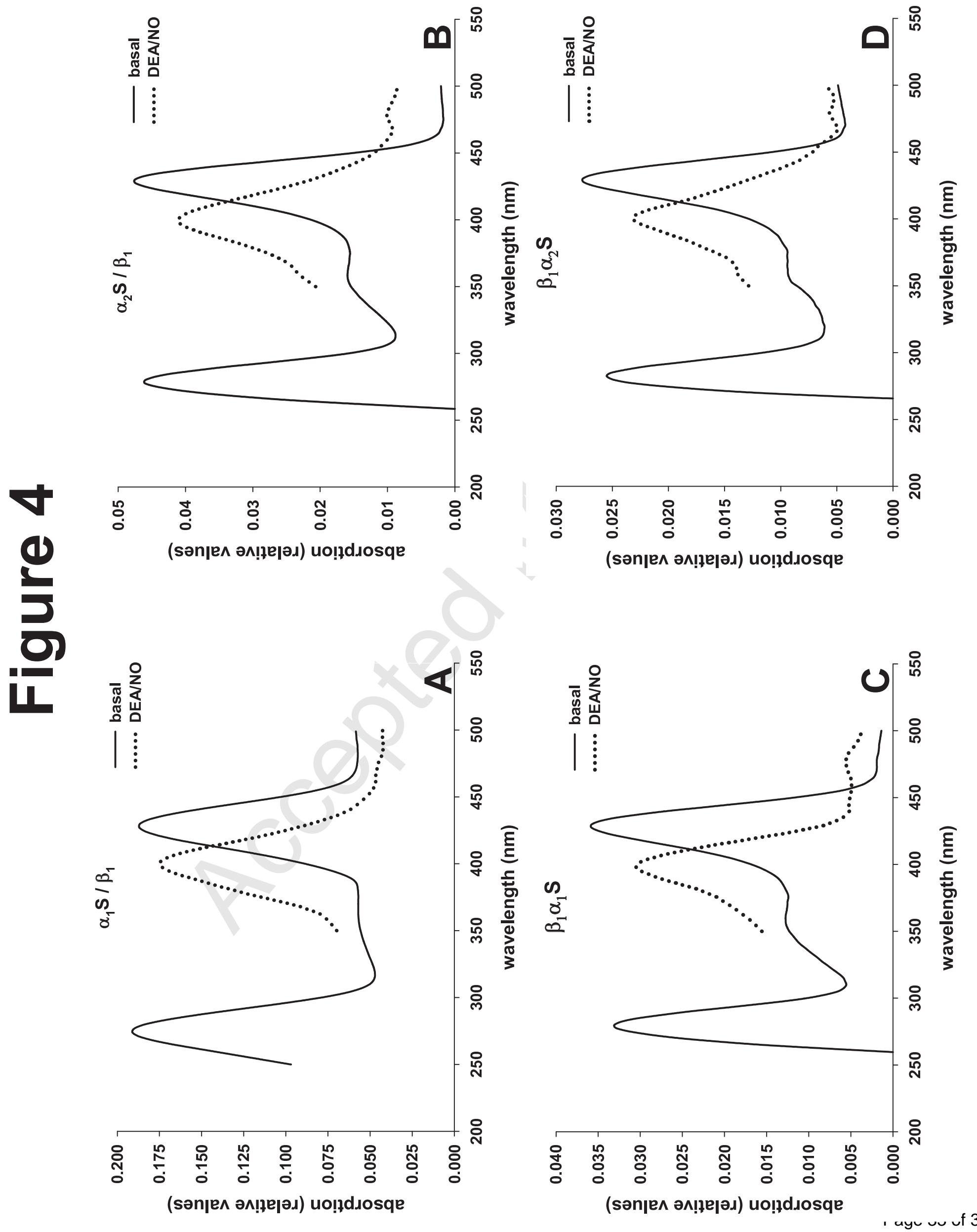




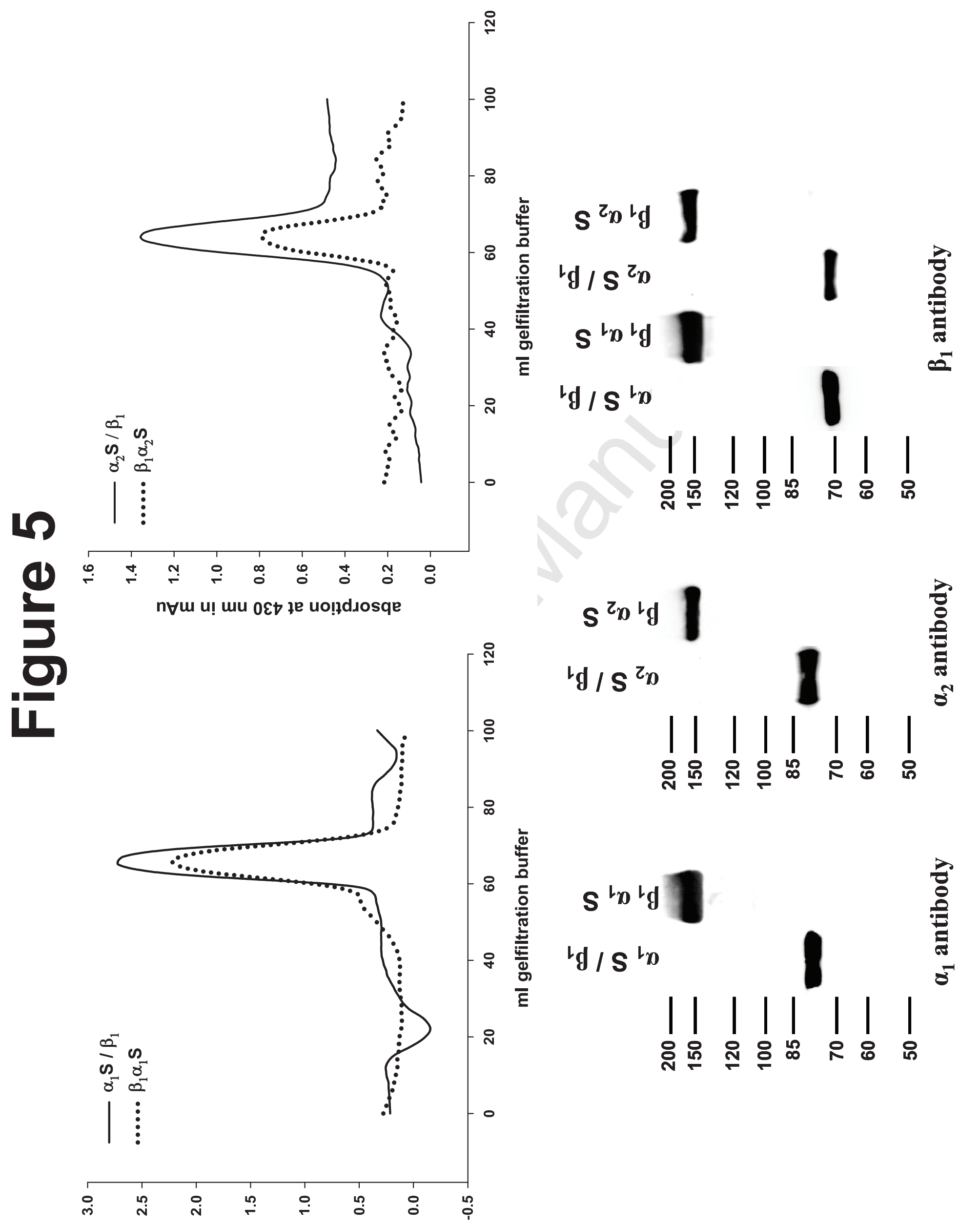



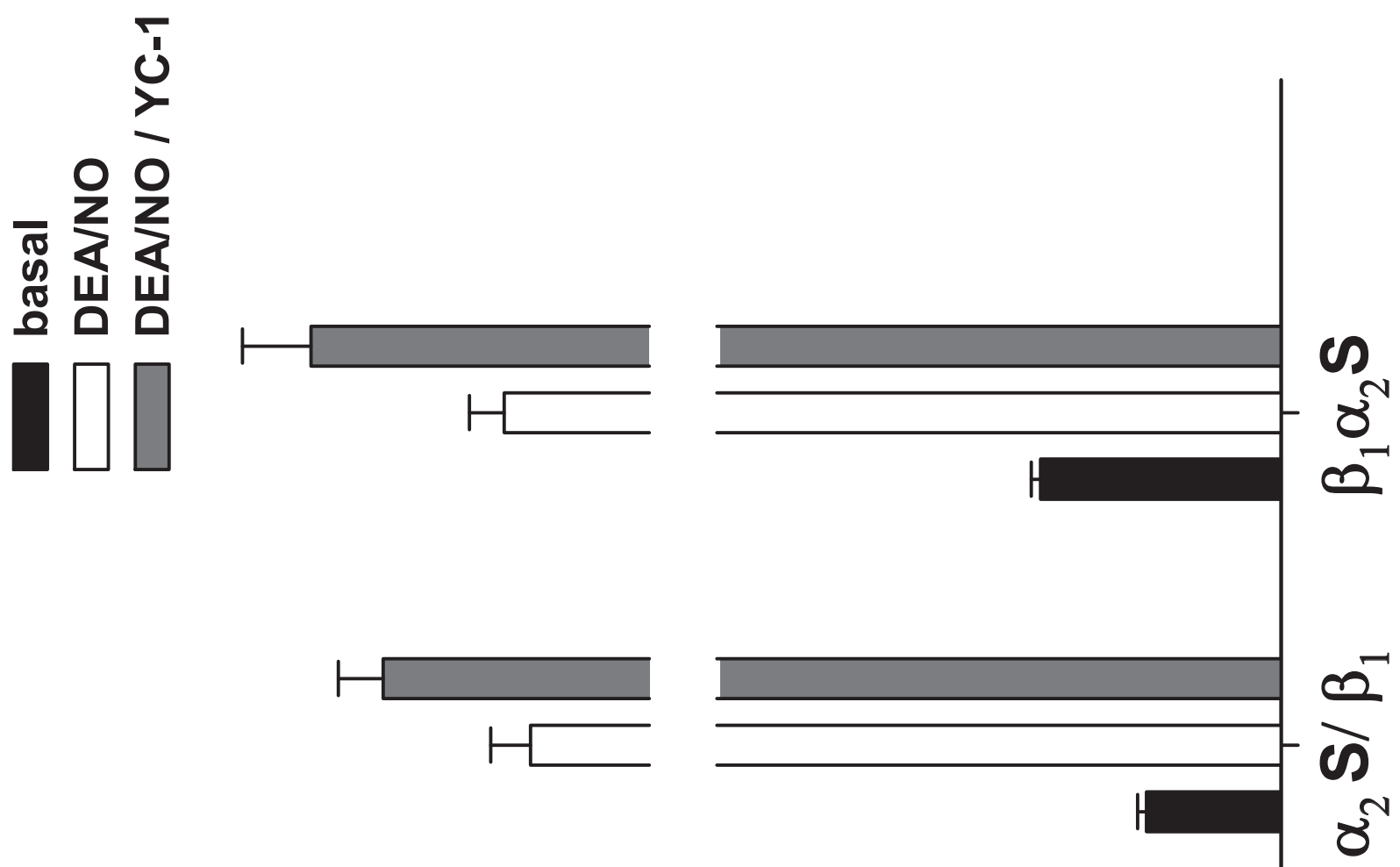

(2)

(2)
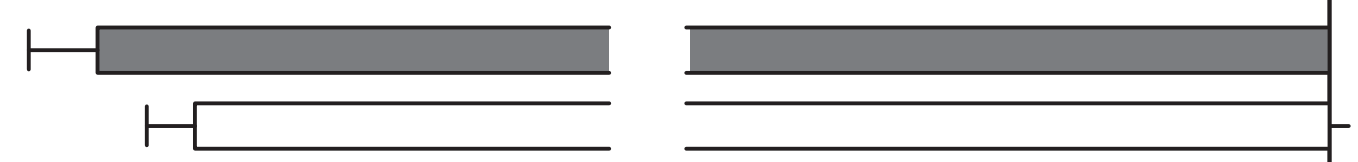

$\boldsymbol{\infty}$
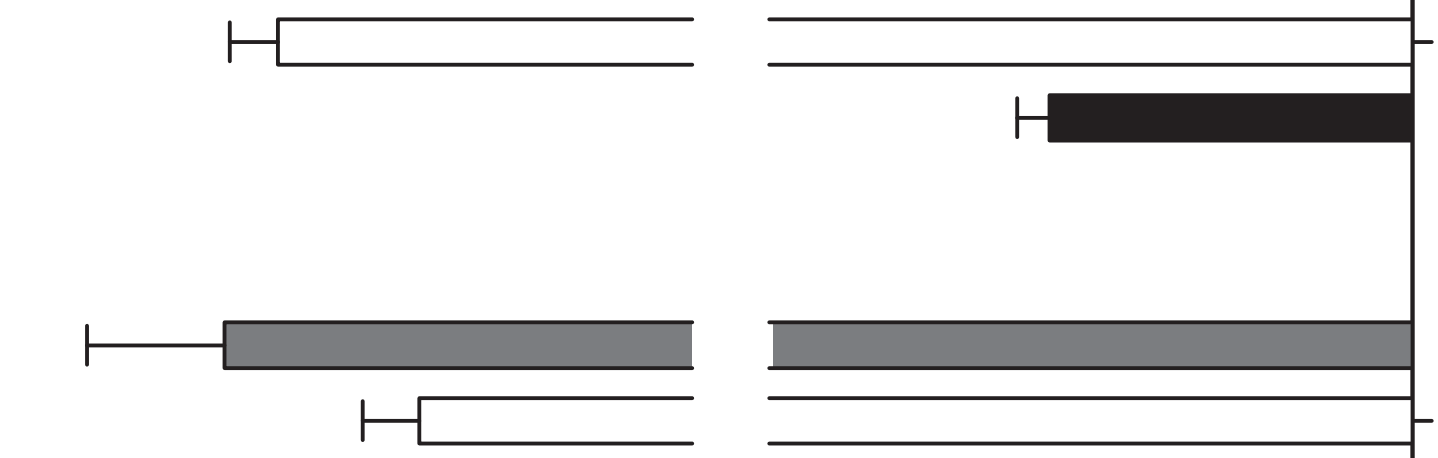

व

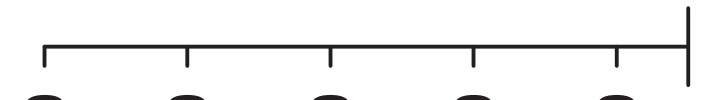

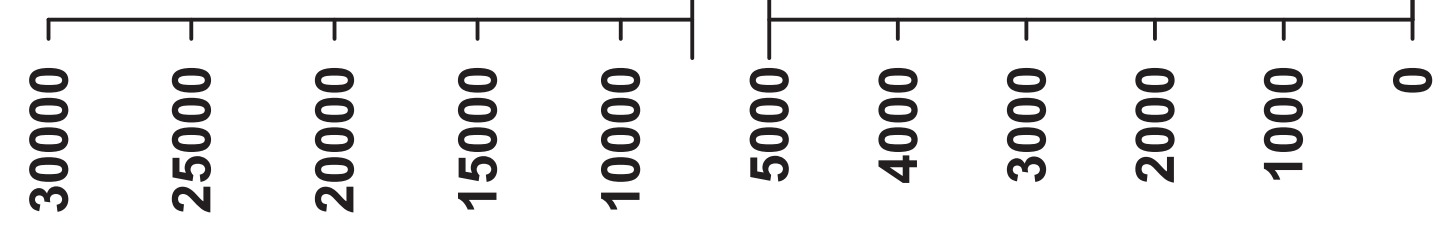

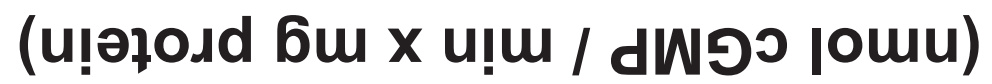

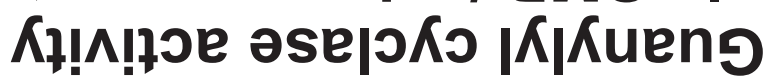




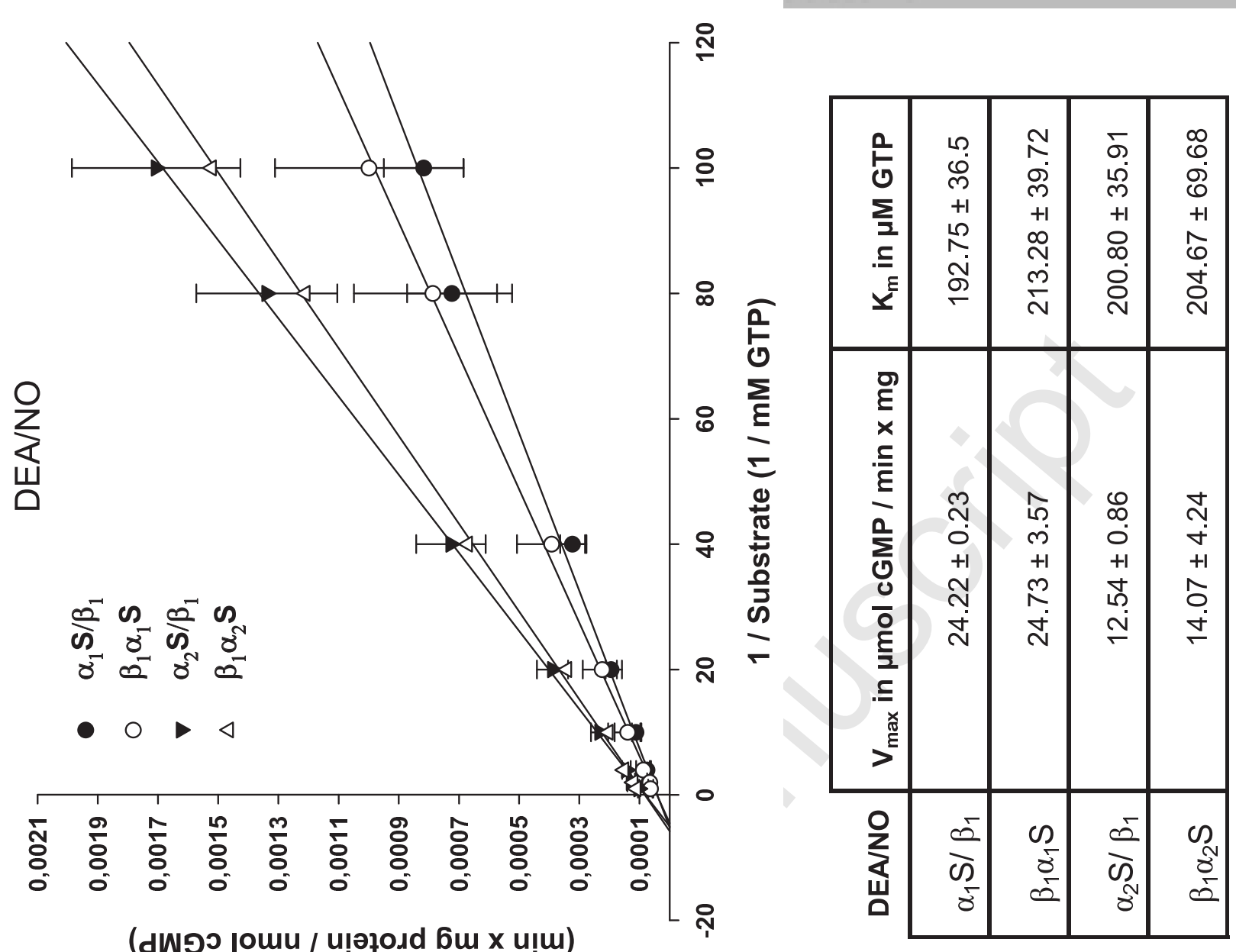

$\frac{1}{5}$ (dWפग ןomu / u!əłodd bu x u!̣)

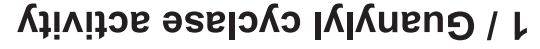
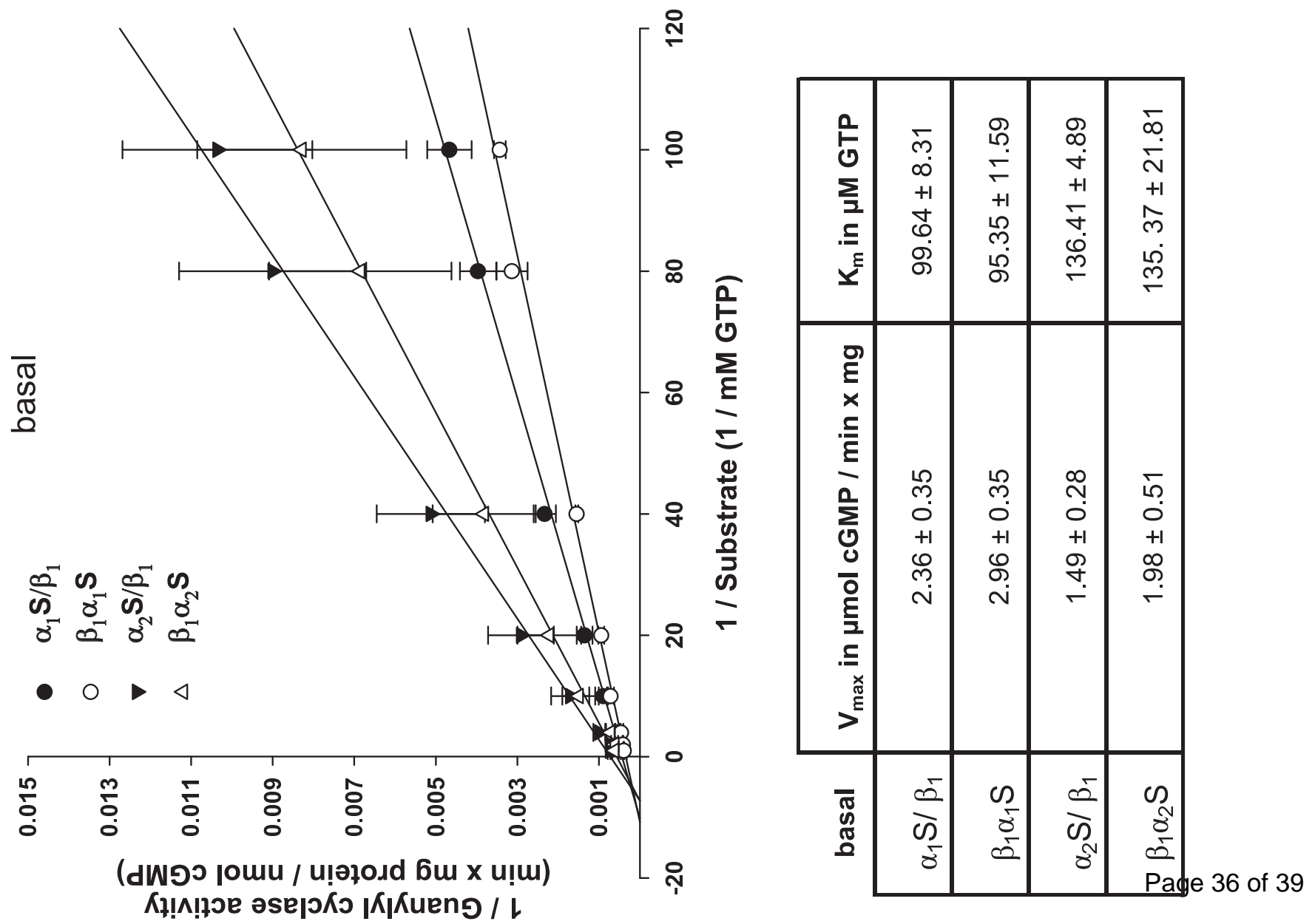


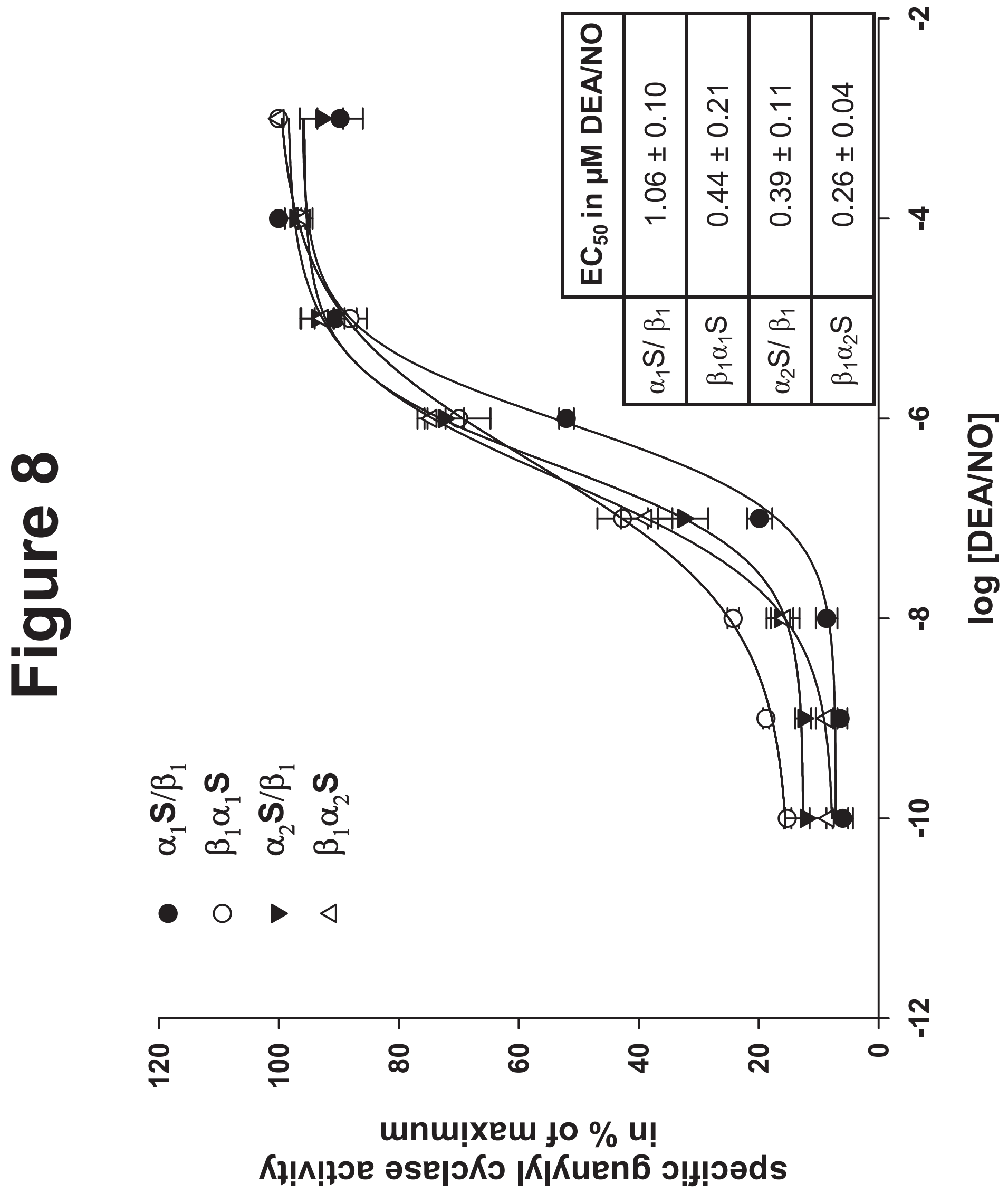

Page 37 of 39 

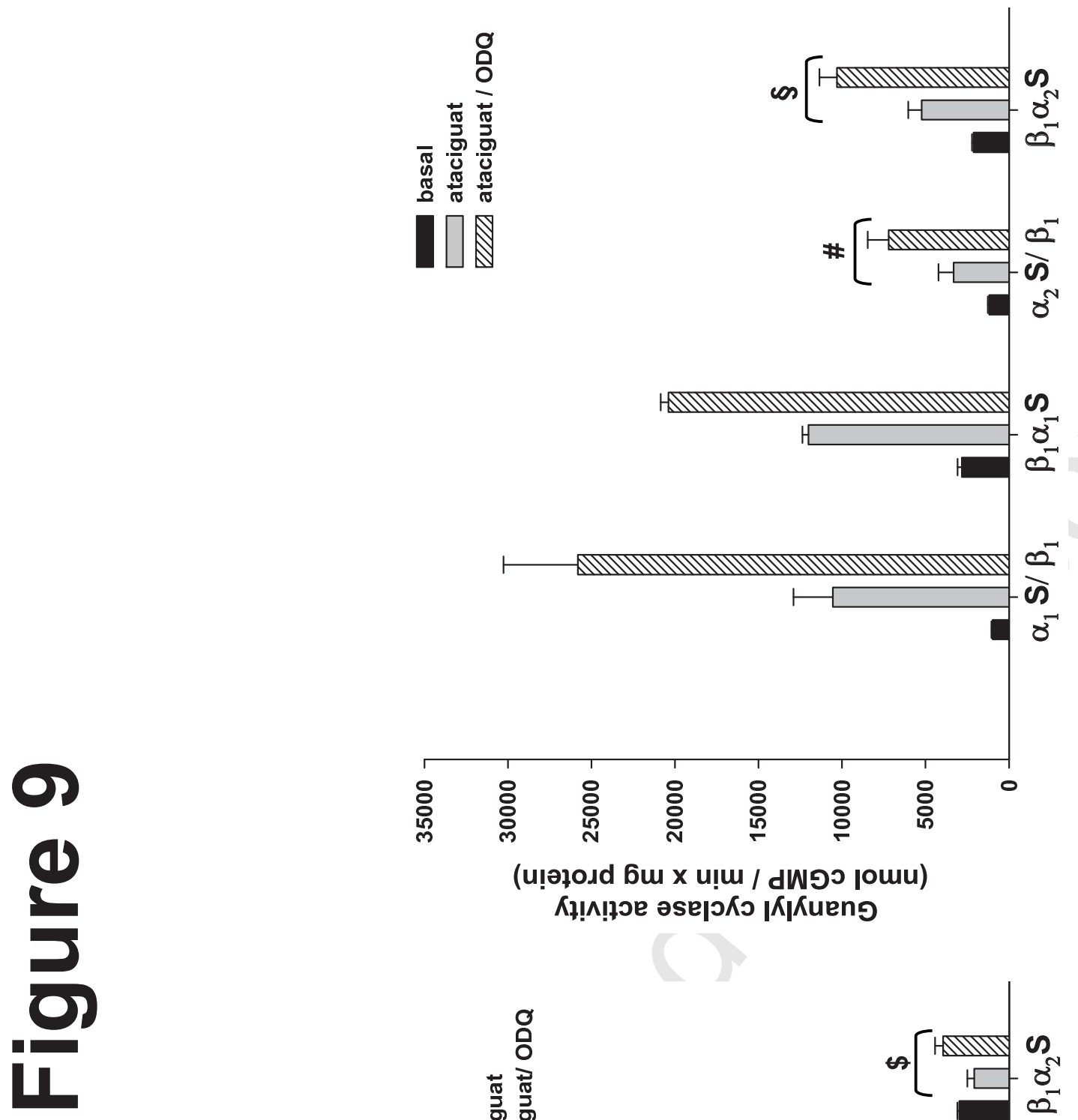

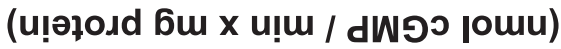

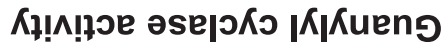

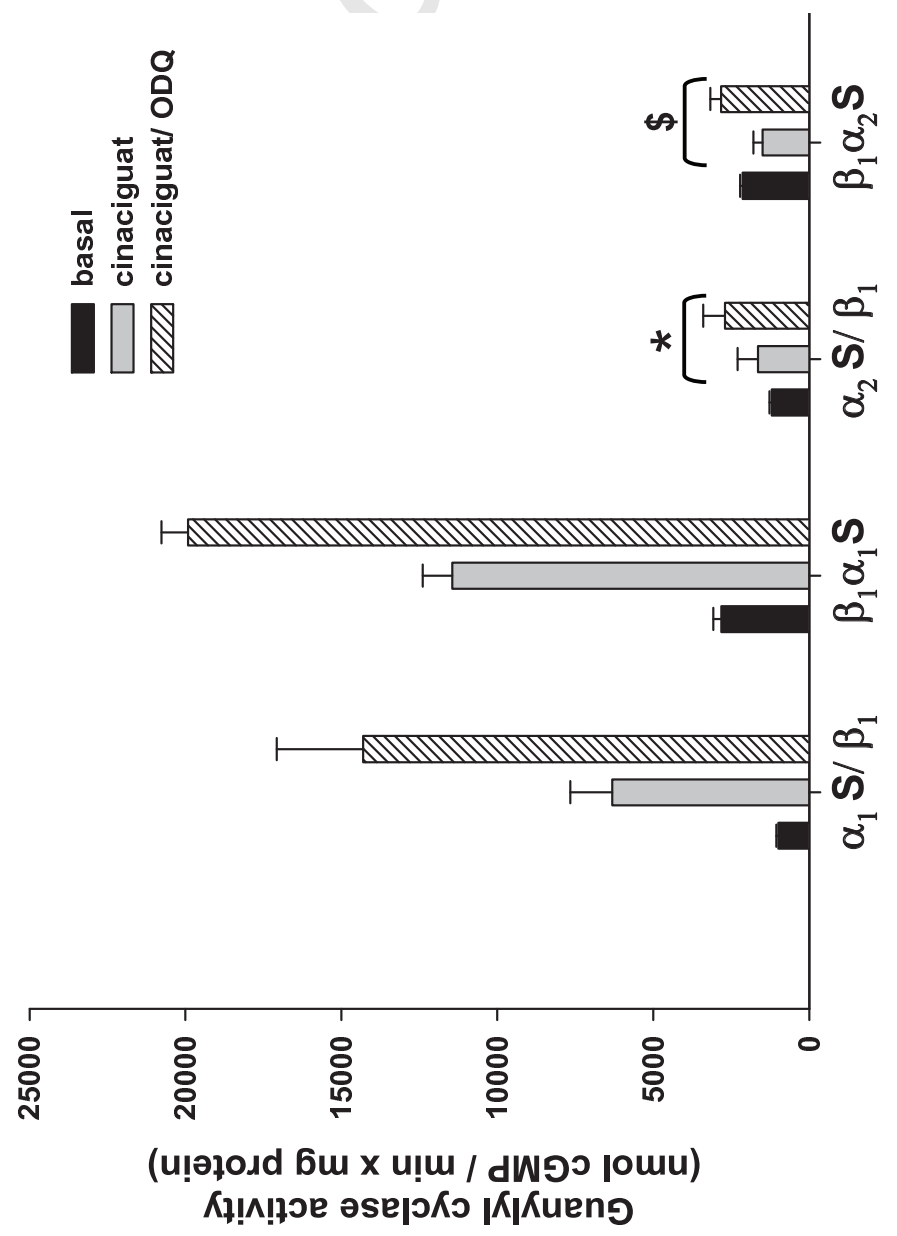




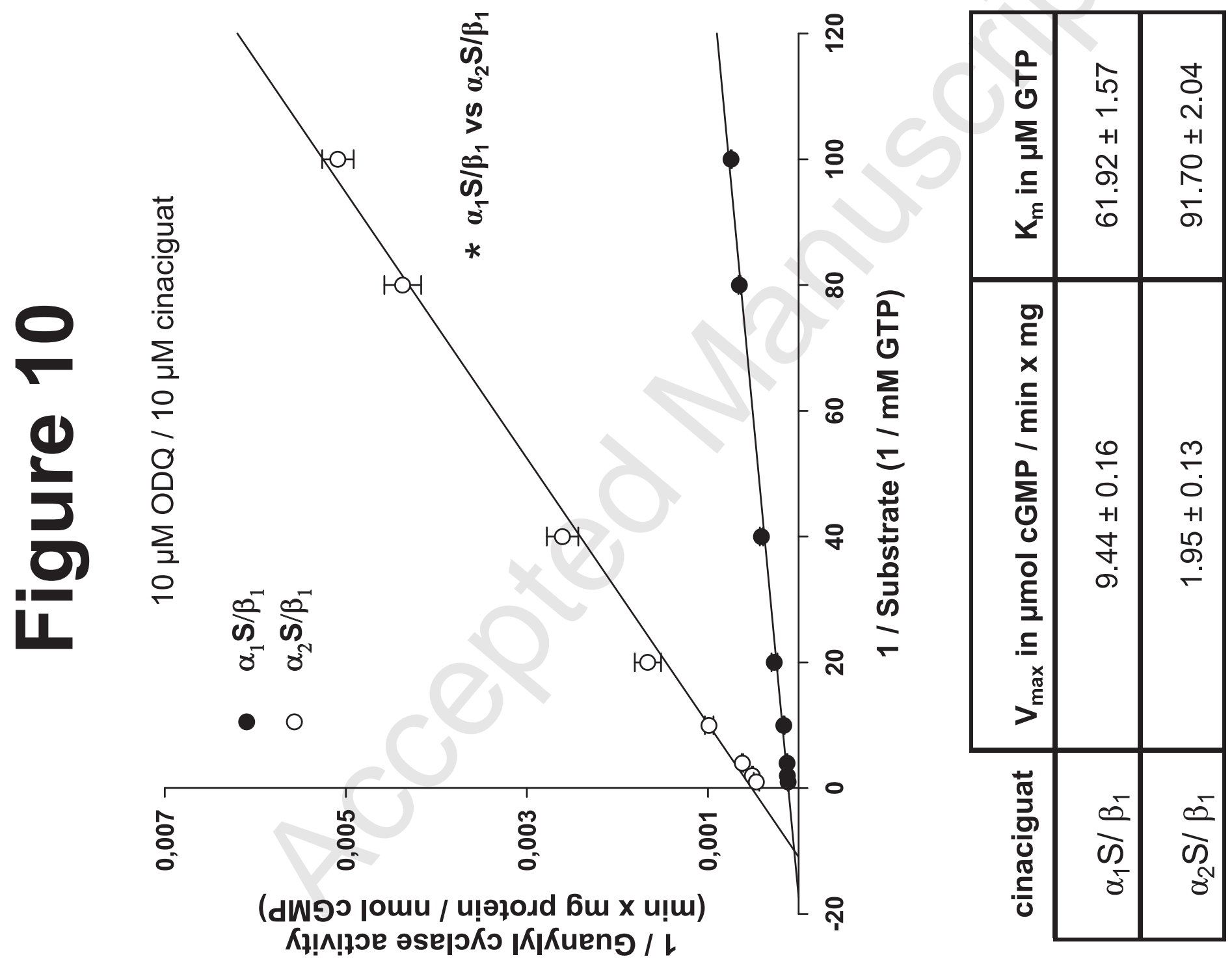

